\title{
Micromorphological features of soils formed on calcium carbonate-rich slope deposits in the Polish Carpathians
}

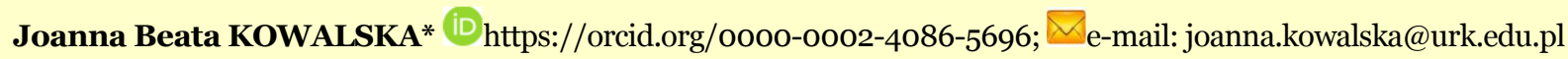 \\ Tomasz ZALESKI iD https://orcid.org/oooo-00o2-9785-3784; e-mail: tomasz.zaleski@urk.edu.pl \\ Ryszard MAZUREK [Deceased]
}

Department of Soil Science and Agrophysics, University of Agriculture, Al. Mickiewicza 21, 31-12o Kraków, Poland

Citation: Kowalska JB, Zaleski T, Mazurek R (2020) Micromorphological features of soils formed on calcium carbonate-rich slope deposits in the Polish Carpathians. Journal of Mountain Science 17(6). https://doi.org/10.1007/s11629-019-5829-5

(C) The Author(s) 2020.

\begin{abstract}
Seven soil profiles developed on calcium carbonate-rich slope deposits in the Polish Carpathians were studied in order to: i) determine the micromorphological features of heterogeneous soils formed in a carbonate depositional environment, and ii) track primary and secondary calcium carbonate forms and their distribution in such stratified soils. Three cases of soils with different arrangements of calcium carbonate were distinguished, controlled mostly by slope processes. For instance, the increasing content and random distribution of angular and subangular rock fragments found in the overall soil matrix and the irregular coarse: fine size limit suggested different intensities of accumulation and mixing of soil material transported along the slope. Slope processes, together with the calcium carbonate content, mineralogical characteristics and texture influenced the type and arrangement of the bfabric pattern. The calcium carbonate distribution within the soils, besides the obvious inheritance from parent material, was governed by the translocation and mixing of deposits on slopes. The climatic conditions prevailing in the area favour the development of secondary forms of calcium carbonate. However, only three of the seven studied profiles contained pedogenic forms of calcium carbonate, yet they were distributed randomly. The occurrence, distribution and preservation of secondary carbonates depended on the content of primary calcium carbonate and soil features such as texture. The
\end{abstract}

Received: 01-Oct-2019

Revised: 24-Jan-2020

Accepted: 25-Feb-2020 transported material down the slope may indicate a very low content of primary calcium or lack thereof, hence its pedogenic forms could not be created.

Keywords: Heterogeneous soils; Microfacies; Secondary calcium carbonate; Pedofeatures; Soil profile

\section{Introduction}

Soils located on slopes often exhibit a high level of heterogeneity and stratification within the solum. The formation of such soils is usually driven by geomorphological activity, mostly slope processes of various durations and intensities (Alijani and Sarmandian 2014; Badía et al. 2013; Kacprzak and Derkowski 2007; Kowalska et al. 2017; Waroszewski et al. 2013, 2015). Often, the development of mountain soils is also supported by admixture of allochthonous materials, which is an additional cause of their heterogeneous character (Jäger et al. 2015; Philips and Lorz 2008; Waroszewski et al. 2015, 2018).

The heterogeneity of soils developed from slope deposits can be seen in macroscopic observations of morphological features such as sudden changes within the grain size distribution (Kowalska et al. 2017; Waroszewski et al. 2013, 2015), the presence of rock fragments with different lithology, a significant change of 
percentage content and/or shape of coarse fragments (Kacprzak and Derkowski 2007; Kowalska et al. 2019), various degrees of soil weathering, and changes in the colour mantle or the soil conciseness (Schaetzl and Anderson 2005). However, transported, displaced and mixed material on slopes can be also efficiently recognized by a number of micromorphological features. Sometimes, even in the absence of macroscopic indications, the analyses of micromorphological features can give even more detailed insight (Bertran and Texier 1999; Mücher et al. 2010).

Unfortunately, micromorphological features in soils affected by slope processes have not received much attention in recent years. Reviewing the literature, the most complex investigations were published nearly forty years ago and were associated with micromorphological aspects mainly concerning solifluction deposits (e.g. Harris 1981; Harris and Ellis 1980; Mücher et al. 2010 and references cited in each) and colluvial deposits (e.g. Govers et al. 1994; Mücher and Morozova 1983; Mücher et al. 1981; van Oost et al. 2000; van Muijsen et al. 2002). The 1990 s abounded in fairly well documented micromorphological studies concerning slope deposits (see Mücher et al. 2010 and references therein). According to these authors, translocated or displaced material may be recognized by the presence of horizontally oriented rock fragments, rounded or subrounded rock fragments and/or subangular aggregates composed of material derived from other soil horizons, as well as certain pedofeatures, e.g. ferruginous nodules, often with sharp boundaries, and variously distributed clay secondary forms with disorientated character. However, the intensity and duration of slope processes can deeply alter original microstructures within the slope deposits in terms of the character, size and the abundance of micromorphological features.

Many scientists have shown an interest in the calcium carbonate features visible in thin sections in various kinds of soils (Durand et al. 2010; Sehgal and Stoops 1972; Wieder and Yaalon 1974). One of the most comprehensive overviews has been given by Reeves (1970), dealing mainly with diagenetic carbonate features and their classification and origin. Some authors have focused on a general description of calcium carbonate microfeatures in terms of their shape, properties and morphology (e.g. Bullock et al. 1985). Further studies have investigated the mechanism of formation and development of secondary calcium carbonate features, which are precipitated and very often subjected to recrystallization (Durand et al. 2007, 2010; Zamianian et al. 2016) and dissolution processes (Alonso et al. 2004; Zamanian et al. 2016).

However, the occurrence and distribution of calcium carbonate microfeatures in mountain soils can be more complex than other areas, because of the activity of slope processes that control their translocation as well as their various distribution within the solum (Alijani and Sarmandian 2014; Bockheim and Douglass 2006; Gargiulo et al. 2013). To date, there have also been a few studies that have given attention to calcium carbonate microfeatures within slope deposits, but these studies have a rather local character. Zasoński (1992, 1993, 1995a,b) has defined a set of characteristic micromorphological features of calcium carbonate soils on slopes within the Carpathian Foothills and Eastern Carpathians (South Poland). Afterwards, Zagórski (1999) studied the micromorphological features of carbonate soils developed under very variable geological conditions with a strong influence of ancient and contemporary deluvial processes, in the area of the Pieniny Mts. (Polish Carpathians). More recently, Kacprzak and Żyła (2006) supported the thesis that microstructures and pedofeatures observed in micromorphological analyses can confirm the occurrence of lithic discontinuities between slope cover and bedrock in carbonate-rich Cambisols. On the other hand, Kolesár and Čurlik (2015) investigated autogenous carbonate accumulations in loess soils, using Trnavská pahorkatina loess hilly land (SW Slovakia) as their case study.

Nevertheless, none of the abovementioned studies focused on both the influence of slope processes on micromorphological features in soils developed from slope deposits and assessments of the occurrence and distribution of lithological and pedogenic forms of calcium carbonate in such heterogeneous soils. Therefore, the aim of this study was to give a more detailed insight into the above-stated problems by assessing the micromorphological picture of mountain slope soils. 


\section{Materials and Methods}

\section{1 Study area and sampling procedure}

The study focused on seven soil profiles located within the Polish part of the Carpathian Mts. (Figure 1), where Jurassic and Cretaceous sedimentary formation prevailed and which mainly present calcium carbonate-rich rocks, e.g. limestone and marl, as parent material. Carpathian flysch sediments occur as well, e.g. sandstones, shales and conglomerates, also indicating the carbonate character of the region (Skiba 1995).

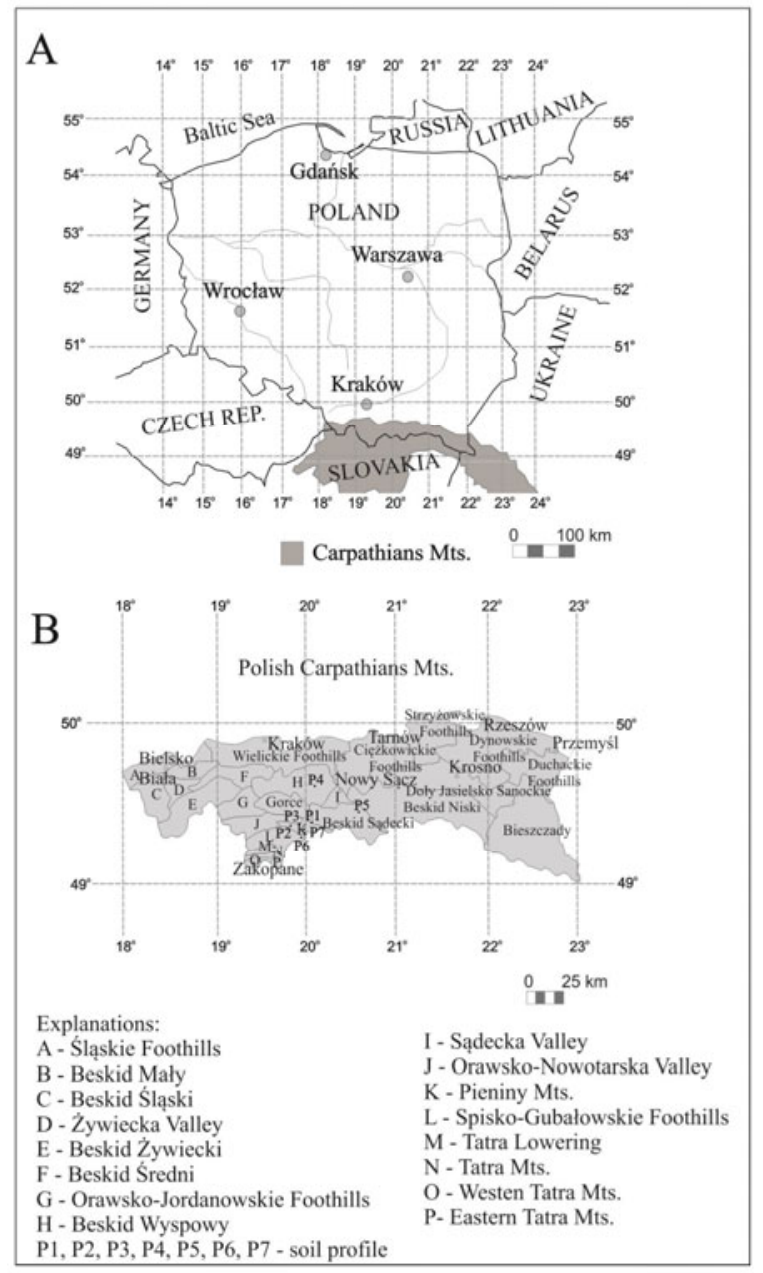

Figure 1 Location of soil profiles within the Polish part of the Carpathian Mts. A) outline map of Poland and neighbouring countries; B) map of physicogeographical regions of the Polish Carpathians.

The soil cover of the Carpathian Mts. is a function of lithology, relief and vegetation. A few types of soils may be distinguished. Generally, the occurrence of limestone and marl as well as other calcium carbonate-rich rocks (e.g. sandstone, shale) provides parent material for Leptosols, Eutric Cambisols and Regosols (60\%). In some parts, Dystic Cambisols occur (30\%), which developed on more acidic rocks (mostly alluvial material). Further, a small part of the Carpathian Mts. soil cover (10\%) consists of Stagnosols, Gleysols as well as Regosols, formed on siliceous and non-carbonate substrates (Kowalska et al. 2017, 2019; Skiba 1995).

The mean annual air temperature for the western Carpathians Mts. ranges between $6^{\circ} \mathrm{C}$ and $8^{\circ} \mathrm{C}$ at $700 \mathrm{~m}$ a.s.l. and $4^{\circ} \mathrm{C}-6^{\circ} \mathrm{C}$ at $1100 \mathrm{~m}$ a.s.l. At the highest elevations, the mean air temperature ranges between $2^{\circ} \mathrm{C}$ and $4^{\circ} \mathrm{C}$ (Otrębska-Starklowa et al. 1995). Mean annual precipitation varies between 400 and $700 \mathrm{~mm}$. The sum of evaporation can reach up to $300-400 \mathrm{~mm}$ in the period from May to October. The duration of snow cover is about 120 days per year on the highest peaks (Otrębska-Starklowa et al. 1995).

The soils under study show seven different examples of calcareous parent material as well as various patterns of calcium carbonate distribution within the profile (Figure 2). The soils have developed from various carbonate-rich colluvial materials (Table 1) and represent different reference soil groups according to the World Reference Base for Soil Resources (IUSS Working Group 2015; Table 1). Meteorological data (the sum of precipitation, evaporation and the temperature) given by Kuźniar et al. (2011) and the collection of the Polish Institute of Meteorology and Water Management for the period 1990-2005, from selected meteorological stations located near the studied soils (Limanowa, Krościenko nad Dunajcem, Rabka, and Niedzica) were used for this study.

Soil samples were collected from all designated soil horizons (39 genetic horizons in total) for further micromorphological and physicochemical analyses. Soils were sampled under normal humidity conditions (moist). Characteristics of their morphology were identified, and a detailed description of the soil profiles constructed in accordance with the requirements of FAO (2006). The $\mathrm{O}$ horizons were not taken into account during the morphological and micromorphological description of the soil profiles. The soil samples were air-dried and sieved through 

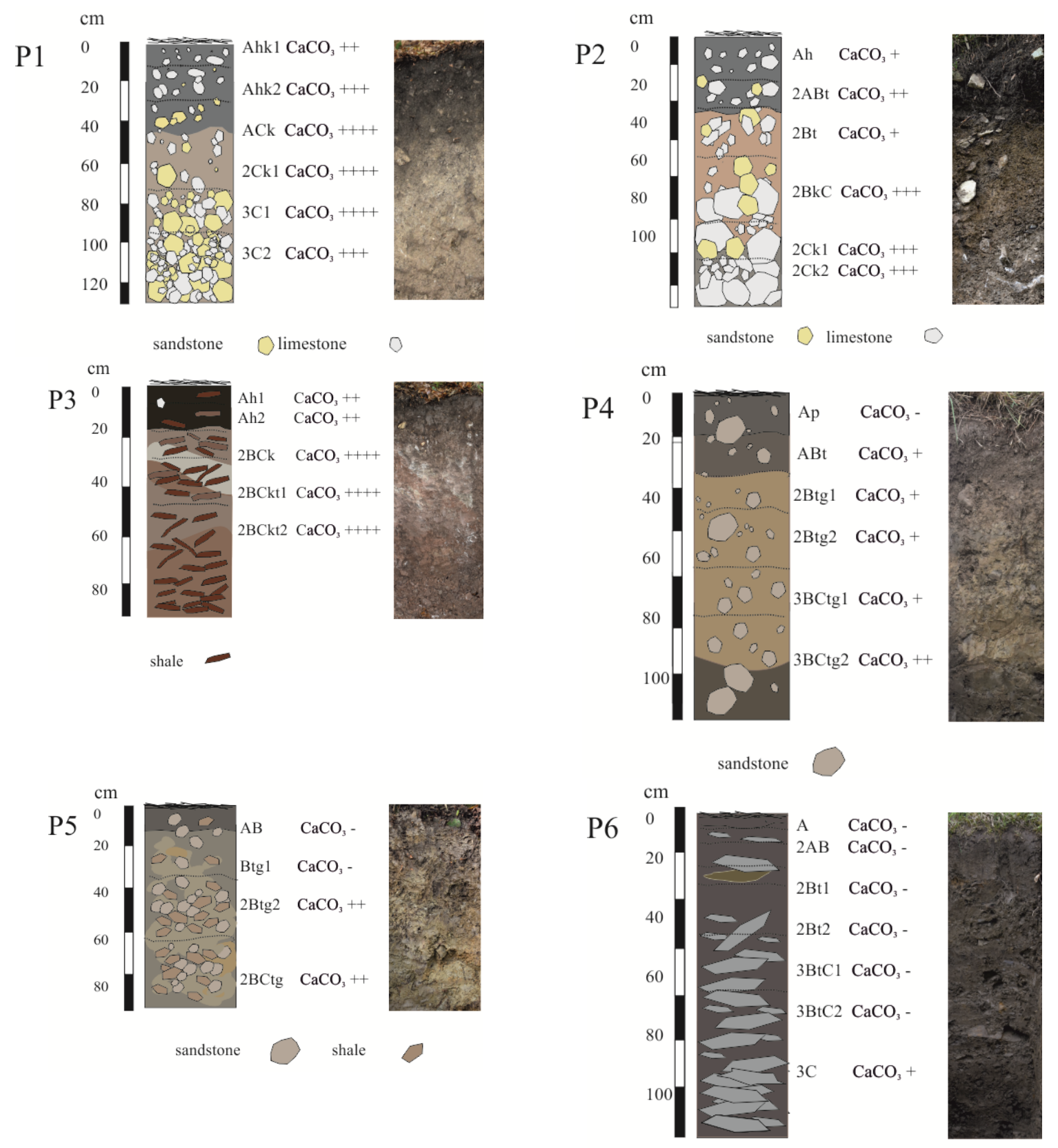

menilite shale
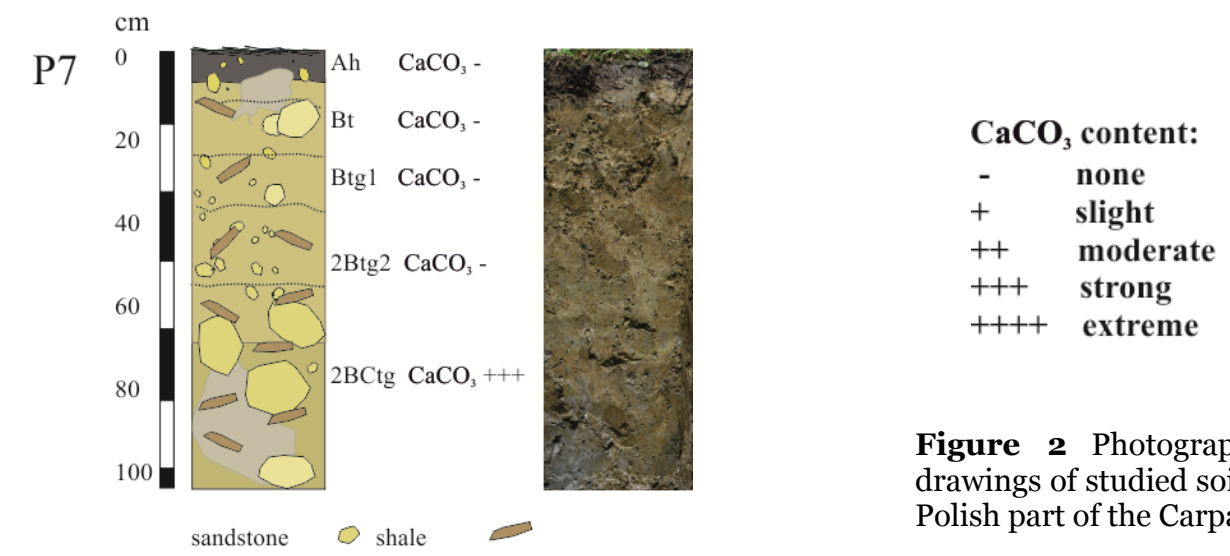

Figure 2 Photographs and simplified drawings of studied soil profiles within the Polish part of the Carpathian Mts. 


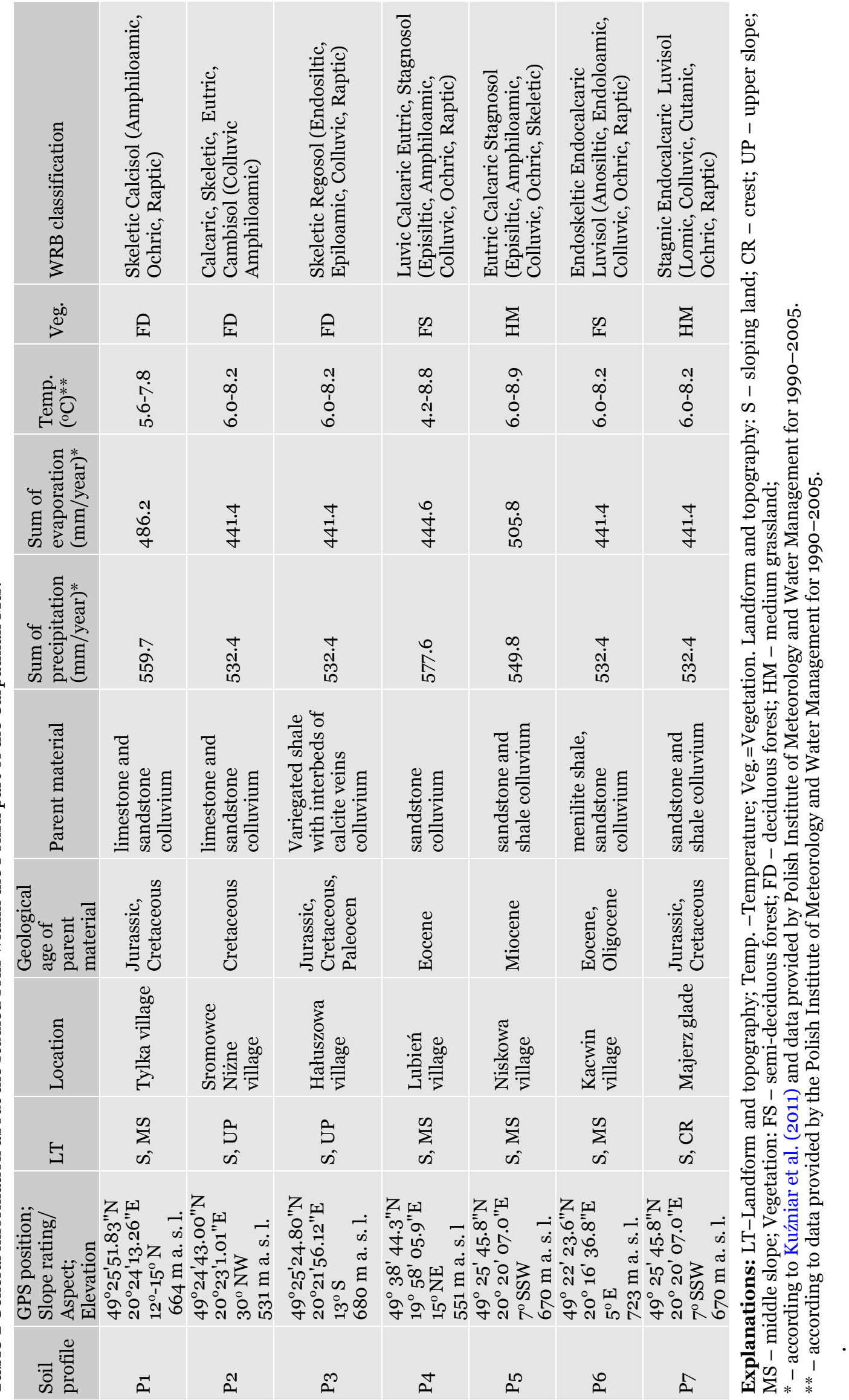


a certified plastic sieve ( $2 \mathrm{~mm}$ diameter). For all soil samples, besides the micromorphological analysis, the following analyses were performed: total organic carbon (TOC), total nitrogen (TN) and calcium carbonate $\left(\mathrm{CaCO}_{3}\right)$ content, soil texture, $\mathrm{pH}$, as well as total potential acidity and base saturation. The colour of each separate horizon was determined using the Standard Soil Colour Charts (Munsell 1975).

\subsection{Physical and chemical analyses}

The soil texture was determined using the Bouyoucos aerometric method according to the Polish standard PN-R-04032 (1998). Potentiometric measurements of $\mathrm{pH}$ were taken using a standard combination electrode and a CPI551 Elmetron $\mathrm{pH}$ meter in $1 \mathrm{M} \mathrm{KCl}$ solution at a ratio of 1:2.5 and $\mathrm{H}_{2} \mathrm{O}$. TOC content was determined by applying the Tiurin method, using potassium dichromate and Mohr's salt without the removal of calcium carbonate. TN content was determined using the Kjeldahl method (Lityński et al. 1976) on a FOSS Kjeltec TM 8100 apparatus. Total $\mathrm{CaCO}_{3}$ content was determined by the Scheibler method using hydrochloric acid (Lityński et al. 1976). The evaluation of base saturation was calculated from the total potential acidity (TPA), which was assessed via incubation of soil samples in $0.5 \mathrm{M}$ of calcium acetate at $\mathrm{pH} 8.2$, and the sum of exchangeable bases $\left(\mathrm{Ca}^{2+}, \mathrm{Mg}^{2+}, \mathrm{Na}^{+}\right.$and $\left.\mathrm{K}^{+}\right)$, assessed via extraction in $1 \mathrm{M}$ ammonium acetate at pH 7.0 (Kociałkowski et al. 1984) and analysis with an ICP-OES Optima 7300 DV.

\subsection{Micromorphological soil characteristics}

In order to provide a comprehensive analysis of the micromorphological features in the studied soils, thin sections from undisturbed soil material were prepared with a 'Kubiena box'. Sampled soil material with undisturbed structure was consolidated in an Epovac vacuum chamber and impregnated using either an epoxy resin (Araldite ${ }^{\circledR}$ 2020) for profile $P 1$, or a polyester resin (POLIMAL ${ }^{\circledR}$ 109) for profiles P2, P3, P4, P5, P6, P7. Thin sections were prepared by a set of special equipment, including an Epovac vacuum chamber (Struers ${ }^{\circledR}$ ), a CS30 saw for soil sample cutting (Struers ${ }^{\circledR}$ ), a CL5O apparatus for precision lapping of thin sections $\left(\operatorname{Logitech}^{\circledR}\right.$ ) as well as a CL5O apparatus for thin-section polishing (Logitech ${ }^{\circledR}$ ). Microscopic observation of thin sections was conducted using a Nikon Eclipse 400 microscope, using both plane- and cross-polarized light. Each thin section was described in accordance with the nomenclature proposed by Stoops (2003).

\section{Results}

Based on morphological features and primary and secondary calcium carbonate content and their distribution (Table 2, Table 4), the soils under study were classified into three main groups indicating different calcium carbonate arrangements within the soil profiles. However, all soils had calcium carbonate-rich $\mathrm{C}$ horizons. The groups were as follows: (1) lithogenic (and in some horizons also pedogenic) calcium carbonate was present in all horizons; (2) lowermost B and C horizons showed primary calcium carbonate; (3) slight or strong content of primary calcium carbonates present only in the $\mathrm{C}$ horizons.

\subsection{Group 1: Calcium carbonates occurred in every soil horizon}

\subsubsection{Morphological characteristics, chemical properties and texture}

The presence of primary calcium carbonate in all soil horizons was characterized in three soil profiles, - P1, P2 and $\mathrm{P}_{3}$ - classified as Calcisol, Cambisol and Regosol, respectively (Table 1, Figure 2). However, in the field any secondary forms of calcium carbonate were recognized; the pedogenic calcium carbonate was visible only in the thin sections. The number of coarse fragments in these soils was highest in the $\mathrm{BC}$ and/or $\mathrm{C}$ horizons and generally increased with depth. The shape of coarse fragments was mostly angular ( $\mathrm{P}_{2}$ and $\mathrm{P}_{3}$ ) or angular/subangular (P1) (Table 2).

The texture of soils varied within the individual soil profiles, highlighting their strong vertical stratification. The uppermost soil horizons $(\mathrm{A}, \mathrm{AB})$ were characterized by sandy loam (profile P1), sandy loam/loam (profile P2) or silt clay loam (profile $\mathrm{P}_{3}$ ) textures, much coarser than the underlying horizons (Table 3). This suggests a different origin for the materials that composed the 


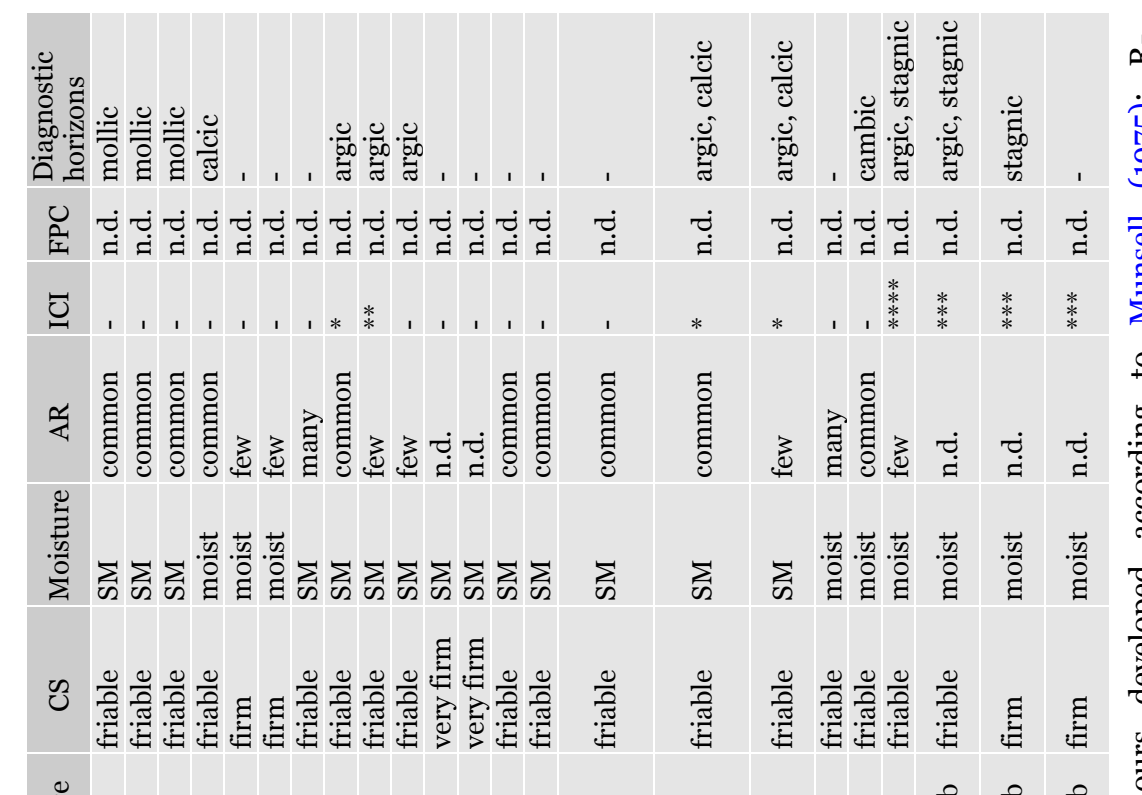

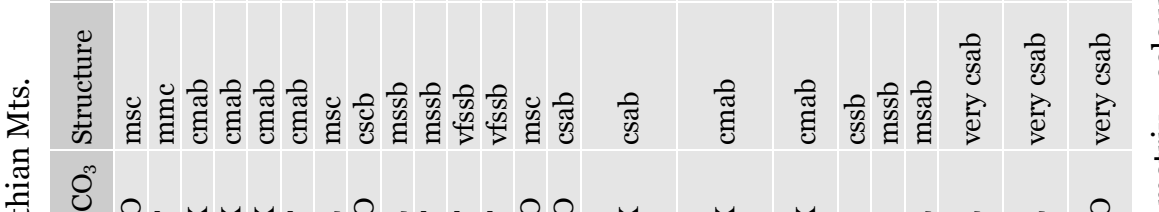

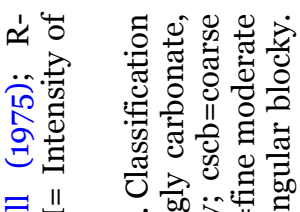

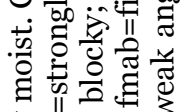

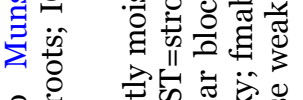

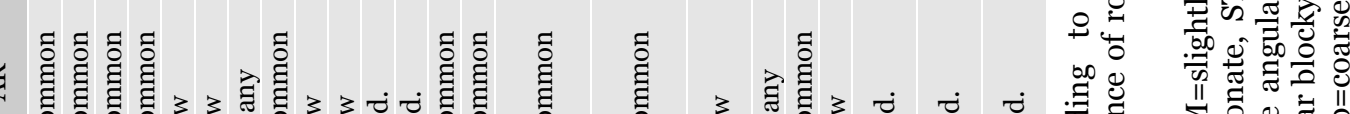

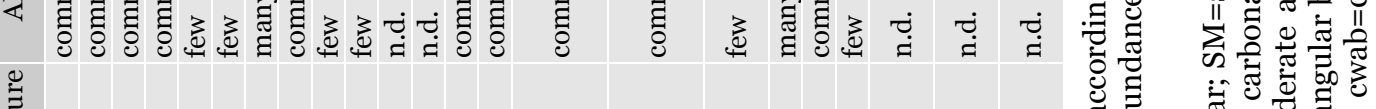
营

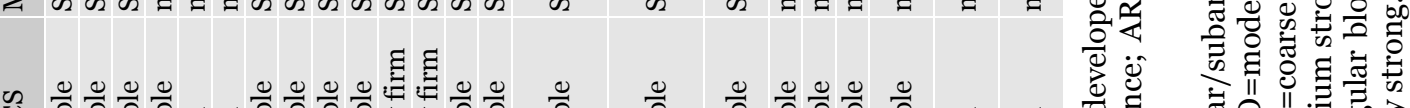

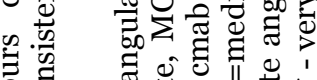

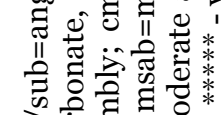
吾 Uू 


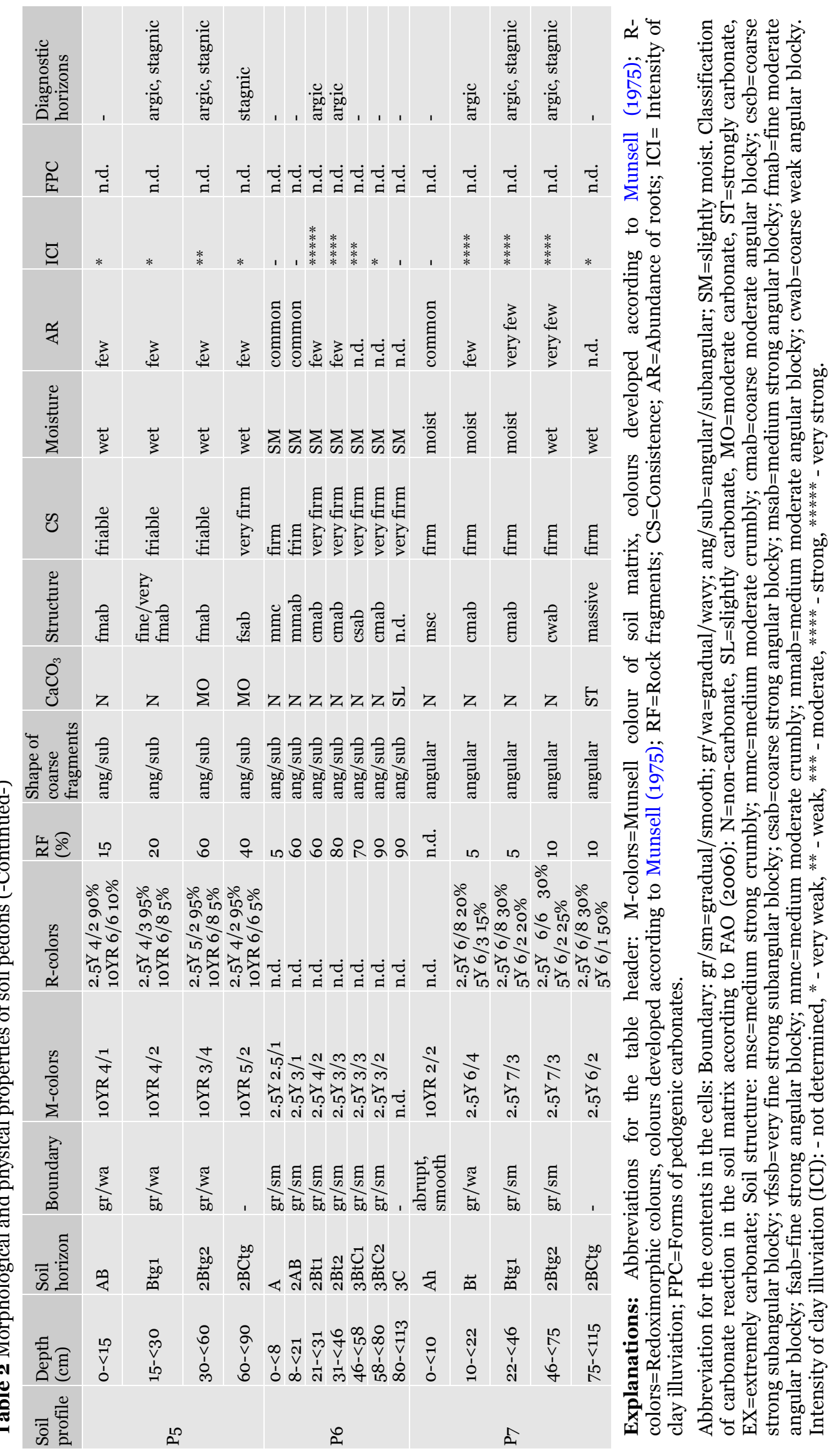


topsoil. The lowermost horizons also showed a variable texture in each profile. Within $\mathrm{P} 1$, the lowermost horizons had loam and silt loam textures (Table 3). The silt fraction prevailed in the lowermost horizons of P2, where clay loam, loam and silty clay loam textures were noted. Similarly, a silt fraction prevailed in $\mathrm{P}_{3}$. The lowest horizons of $\mathrm{P}_{3}$ had clay loam and silt loam particle size classes (Table 3).

Each profile of Group 1 was characterized by $\mathrm{pH}$ values increasing with depth (Table 4). The $\mathrm{pH}$ values varied vertically within the profiles from weakly acidic to neutral, ranging from 7.8 to 8.8 in $\mathrm{H}_{2} \mathrm{O}$ and from 6.5 to 7.6 in $\mathrm{KCl}$ solution (Table 4 ). $\mathrm{CaCO}_{3}$ was present in every soil horizon, usually at a very high content (up to $703 \mathrm{~g} \cdot \mathrm{kg}^{-1}$ in the middle part of P1, Table 4).

\subsubsection{Micromorphological soil characteristics}

Soils P1, P2 and P3 were characterized mostly by subangular blocky (Figure 3e) and vughy microstructure with a predominance of planar (Figure 3c, e) and vughs (Figure 4a, c, e; Figure 5a, c, e) types of voids, Additionally, within profile P1 a

Table 3 Soil texture of the studied soils within the Polish part of the Carpathian Mts.

\begin{tabular}{|c|c|c|c|c|c|c|c|c|c|c|c|}
\hline \multirow{2}{*}{$\begin{array}{l}\text { Soil } \\
\text { profile }\end{array}$} & \multirow{2}{*}{$\begin{array}{l}\text { Depth } \\
\text { (cm) }\end{array}$} & \multirow{2}{*}{$\begin{array}{l}\text { Soil } \\
\text { horizon }\end{array}$} & \multicolumn{8}{|c|}{ Particle size classes (Unit: \%) } & \multirow[b]{2}{*}{$\begin{array}{l}\text { Texture } \\
\text { group }\end{array}$} \\
\hline & & & $\begin{array}{l}2.0-1.0 \\
\mathrm{~mm}\end{array}$ & $\begin{array}{l}1-0.5 \\
\mathrm{~mm}\end{array}$ & $\begin{array}{l}0.5^{-0.25} \\
\mathrm{~mm}\end{array}$ & $\begin{array}{l}0.25^{-0.1} \\
\mathrm{~mm}\end{array}$ & $\begin{array}{l}\text { 0.1-0.05 } \\
\mathrm{mm}\end{array}$ & $\begin{array}{l}0.05-0.02 \\
\mathrm{~mm}\end{array}$ & $\begin{array}{l}\text { 0.02-0.002 } \\
\mathrm{mm}\end{array}$ & $\begin{array}{l}<0.002 \\
\mathrm{~mm}\end{array}$ & \\
\hline \multirow{6}{*}{ P1 } & $0-<15$ & Ahk1 & 8 & 8 & 9 & 7 & 21 & 15 & 26 & 6 & SL \\
\hline & $15^{-<30}$ & Ahk2 & 13 & 14 & 11 & 9 & 21 & 11 & 17 & 4 & SL \\
\hline & $30-<40$ & $\mathrm{ACk}$ & 10 & 14 & 10 & 5 & 2 & 16 & 29 & 14 & $\mathrm{~L}$ \\
\hline & $40-<65$ & 2Ck1 & 16 & 11 & 6 & 5 & 10 & 11 & 21 & 20 & $\mathrm{~L}$ \\
\hline & $65^{-<90}$ & $3 \mathrm{C} 1$ & 5 & 6 & 5 & 5 & 8 & 16 & 37 & 18 & $\mathrm{SiL}$ \\
\hline & $90-<120$ & $3 \mathrm{C} 2$ & 11 & 11 & 10 & 8 & 6 & 13 & 28 & 13 & $\mathrm{~L}$ \\
\hline \multirow{6}{*}{ P2 } & $0-<22$ & $\mathrm{Ah}$ & 6 & 3 & 2 & 2 & 28 & 5 & 32 & 22 & $\mathrm{~L}$ \\
\hline & $22-<33$ & $2 \mathrm{ABt}$ & 5 & 3 & 2 & 3 & 17 & 13 & 45 & 12 & $\mathrm{SiL}$ \\
\hline & $33^{-<60}$ & $2 \mathrm{Bt}$ & 5 & 4 & 3 & 2 & 9 & 9 & 33 & 35 & CL \\
\hline & $60-<85$ & $2 \mathrm{BkC}$ & 5 & 5 & 4 & 4 & 8 & 14 & 35 & 25 & $\mathrm{~L}$ \\
\hline & $85^{-<110}$ & 2Ck1 & 6 & 6 & 5 & 5 & 4 & 11 & 34 & 29 & $\mathrm{~L}$ \\
\hline & $>110$ & 2Ck2 & 6 & 5 & 5 & 5 & 7 & 12 & 33 & 27 & $\mathrm{~L}$ \\
\hline \multirow{5}{*}{$\mathrm{P}_{3}$} & $0-<7$ & Ah1 & 1 & o & o & 1 & 11 & 13 & 44 & 30 & SiCL \\
\hline & $7-<20$ & Ah2 & 2 & 1 & 1 & 2 & 1 & 10 & 47 & 36 & SiCL \\
\hline & $20-<33$ & 2BCk & 6 & 5 & 4 & 5 & 4 & 27 & 19 & 30 & CL \\
\hline & $33^{-<50}$ & 2BCkt1 & 6 & 4 & 4 & 4 & 3 & 7 & 42 & 30 & CL \\
\hline & $50-<90$ & 2BCkt2 & 3 & 5 & 4 & 5 & 4 & 8 & 46 & 25 & $\mathrm{SiL}$ \\
\hline \multirow{6}{*}{$\mathrm{P}_{4}$} & $0-<18$ & Ap & 2 & 4 & 5 & 3 & 27 & 14 & 41 & 4 & $\mathrm{SiL}$ \\
\hline & $18-<29$ & $\mathrm{ABt}$ & 3 & 4 & 4 & 3 & 8 & 25 & 44 & 9 & $\mathrm{SiL}$ \\
\hline & $29-<48$ & $2 B \operatorname{tg} 1$ & 1 & 2 & 3 & 5 & 8 & 27 & 29 & 25 & $\mathrm{SiL}$ \\
\hline & $48-<70$ & 2Btg2 & O & 1 & 1 & 3 & 7 & 21 & 41 & 26 & SiL \\
\hline & $70-<90$ & 3BCtg1 & 2 & 2 & 2 & 2 & 3 & 15 & 36 & 38 & SiCL \\
\hline & $>90$ & 3BCtg2 & 2 & 2 & 1 & 2 & 1 & 16 & 36 & 40 & SiCL \\
\hline \multirow{4}{*}{$\mathrm{P}_{5}$} & $0-<15$ & $\mathrm{AB}$ & 1 & 1 & 1 & 1 & 15 & 26 & 38 & 17 & SiL \\
\hline & $15^{-<30}$ & Btg1 & 1 & 1 & 1 & 1 & 0 & 24 & 39 & 33 & SiCL \\
\hline & $30-<60$ & 2Btg2 & 3 & 2 & 1 & 2 & 1 & 15 & 40 & 36 & SiCL \\
\hline & $60-<90$ & 2BCtg & 1 & 1 & 1 & 2 & 9 & 5 & 45 & 36 & SiCL \\
\hline \multirow{7}{*}{ P6 } & $0-<8$ & A & 1 & 2 & 1 & o & 53 & 17 & 19 & 7 & SL \\
\hline & $8-<21$ & $2 \mathrm{AB}$ & 1 & 1 & 1 & 2 & 19 & 14 & 39 & 23 & $\mathrm{SiL}$ \\
\hline & $21-<31$ & 2Bt1 & 1 & 1 & 1 & 2 & 6 & 12 & 47 & 30 & $\mathrm{SiL}$ \\
\hline & $31-<46$ & 2Bt2 & 2 & 2 & 2 & 3 & 8 & 15 & 43 & 25 & SiL \\
\hline & $46-<58$ & $3 \mathrm{BtC} 1$ & 2 & 2 & 2 & 2 & 3 & 14 & 46 & 29 & SiCL \\
\hline & $58-<80$ & $3 \mathrm{BtC} 2$ & 3 & 4 & 2 & 2 & 12 & 13 & 38 & 26 & CL \\
\hline & $80-<113$ & $3 \mathrm{C}$ & 3 & 4 & 3 & 3 & 16 & 15 & 33 & 23 & $\mathrm{~L}$ \\
\hline \multirow{5}{*}{ P7 } & $0-<10$ & $\mathrm{Ah}$ & 1 & 2 & 3 & 7 & 18 & 30 & o & 39 & CL \\
\hline & $10-<22$ & $\mathrm{Bt}$ & 1 & 1 & 1 & 5 & 14 & 16 & 31 & 31 & CL \\
\hline & $22-<46$ & Btg1 & 1 & 1 & 1 & 6 & 6 & 21 & 35 & 29 & SiCL \\
\hline & $46-<75$ & 2Btg2 & O & 1 & 2 & 6 & 5 & 21 & 36 & 29 & SiCL \\
\hline & $75^{-<115}$ & 2BCtg & 1 & 2 & 3 & 4 & 10 & 26 & 34 & 20 & SiL \\
\hline
\end{tabular}

Explanations: Texture (FAO 2006): SL - sandy loam, L - loam, SiL - silt loam, SiCL - silty clay loam, CL - clay loam, C - clay, $\mathrm{SiC}$ - silty clay. n.d. - not determined. 
Table 4 Chemical properties of the studied soils within the Polish part of the Carpathian Mts.

\begin{tabular}{|c|c|c|c|c|c|c|c|c|c|c|c|c|c|c|c|c|}
\hline \multirow{2}{*}{$\begin{array}{l}\text { Soil } \\
\text { profile }\end{array}$} & \multirow{2}{*}{$\begin{array}{l}\text { Depth } \\
\text { (cm) }\end{array}$} & \multirow{2}{*}{$\begin{array}{l}\text { Soil } \\
\text { horizon }\end{array}$} & \multicolumn{2}{|l|}{ pH } & \multirow{2}{*}{\multicolumn{2}{|c|}{$\begin{array}{l}\mathrm{CaCO}_{3} \mathrm{TOC} \\
\text { Unit: } \mathrm{g} \cdot \mathrm{kg}^{-1}\end{array}$}} & \multirow[t]{2}{*}{$\mathrm{TN}$} & \multirow{2}{*}{$\mathrm{C}: \mathrm{N}$} & $\mathrm{Ca}^{2+}$ & $\mathrm{Mg}^{2+}$ & $\mathrm{Na}^{+}$ & $\mathrm{K}^{+}$ & & TPA & CEC & \multirow{2}{*}{$\mathrm{BS}(\%)$} \\
\hline & & & $\mathrm{H}_{2} \mathrm{O}$ & $\mathrm{KCl}$ & & & & & \multicolumn{7}{|c|}{ Unit: $\mathrm{mmol} \cdot \mathrm{kg}^{-1}$ of soil } & \\
\hline \multirow{6}{*}{ P1 } & $0-<15$ & Ahk1 & $7 \cdot 7$ & 6.9 & 64.0 & 59.2 & 3.90 & 15.0 & 140 & 5.40 & 1.30 & 5.10 & 8.90 & 152 & 161 & 94 \\
\hline & $15^{-<30}$ & Ahk2 & $7 \cdot 9$ & 7.2 & 148 & 26.7 & 1.70 & $15 \cdot 5$ & 106 & 14.1 & 1.50 & 5.80 & 7.10 & 127 & 135 & 95 \\
\hline & $30-<40$ & $\mathrm{ACk}$ & 8.2 & 7.2 & 360 & 13.2 & 1.80 & $7 \cdot 50$ & 131 & 3.00 & 1.00 & 5.10 & $5 \cdot 40$ & 140 & 145 & 96 \\
\hline & $40-<65$ & 2Ck1 & 8.2 & 7.6 & 703 & 11.6 & 1.00 & 11.7 & 103 & 3.20 & 0.80 & 2.90 & 4.50 & 110 & 115 & 96 \\
\hline & $65^{-<90}$ & $3 \mathrm{C} 1$ & 8.6 & $7 \cdot 4$ & 349 & 9.30 & 0.80 & 11.4 & 131 & 4.00 & 1.00 & 3.50 & 8.00 & 140 & 148 & 95 \\
\hline & $90-<120$ & $3 \mathrm{C} 2$ & 8.5 & 7.4 & 247 & 8.60 & 0.70 & 11.6 & 187 & 6.40 & 1.10 & 8.60 & 3.60 & 203 & 206 & 98 \\
\hline \multirow{6}{*}{ P2 } & $0-<22$ & $\mathrm{Ah}$ & 7.8 & 6.7 & 8.0 & 44.9 & 3.70 & 12.2 & 144 & 7.60 & 1.30 & 3.80 & 13.4 & 157 & 170 & 92 \\
\hline & $22-<33$ & $2 \mathrm{ABt}$ & 8.2 & 6.6 & 11.0 & 25.7 & 2.40 & 10.5 & 200 & 4.40 & 1.20 & 6.10 & 8.00 & 212 & 220 & 96 \\
\hline & $33^{-<60}$ & $2 \mathrm{Bt}$ & 8.5 & 6.8 & & 20.7 & .00 & 21.1 & 187 & 5.60 & 1.90 & $5 \cdot 30$ & 10.7 & 200 & 211 & 94 \\
\hline & $60-<85$ & $2 \mathrm{BkC}$ & 8.7 & 7.1 & 121 & 14.7 & 0.90 & 16.0 & 159 & 3.70 & 1.20 & 5.10 & 6.30 & 169 & 175 & 96 \\
\hline & $85^{-<110}$ & 2Ck1 & 8.7 & 7.1 & 173 & 12.6 & 0.80 & 16.5 & 193 & 5.80 & 3.90 & $5 \cdot 30$ & 6.30 & 208 & 214 & 97 \\
\hline & $>110$ & 2Ck2 & 8.5 & 6.8 & 182 & 10.8 & 0.70 & 14.4 & 225 & 8.50 & 2.10 & 6.60 & 5.40 & 242 & 247 & 97 \\
\hline \multirow{5}{*}{$\mathrm{P}_{3}$} & $0-<7$ & Ah1 & $7 \cdot 3$ & 6.5 & 28.0 & 89.0 & 4.90 & 18.1 & 157 & 6.00 & 1.50 & 5.20 & 8.00 & 170 & 178 & 95 \\
\hline & $7-<20$ & Ah2 & 8.2 & 6.8 & 94.0 & 39.5 & 2.40 & 16.7 & 189 & 6.70 & 1.50 & 4.40 & 8.00 & 201 & 209 & 96 \\
\hline & $20-<33$ & 2BCk & 8.8 & 7.1 & 363 & 16.7 & 0.60 & 29.0 & 141 & 21.2 & 2.50 & 6.50 & 5.40 & 171 & 177 & 97 \\
\hline & $33^{-<50}$ & 2BCkt1 & 8.7 & $7 \cdot 3$ & 370 & 7.50 & 0.50 & $15 \cdot 3$ & 186 & 24.6 & 1.70 & 7.40 & 6.30 & 219 & 226 & 97 \\
\hline & & 2BCkt2 & 8.6 & $7 \cdot 3$ & 260 & 5.70 & 0.50 & 12.8 & 120 & 20.8 & 1.60 & 7.20 & 7.10 & 150 & 157 & 0 \\
\hline & $0-<18$ & Ap & 6.1 & 5.1 & 0.00 & 25.9 & 1.80 & 14.2 & 43.6 & 13.9 & 0.90 & 1.60 & 59.9 & 42.9 & 102 & $5^{8}$ \\
\hline & $18-<29$ & $\mathrm{ABt}$ & 6.1 & 5.2 & 2.20 & 8.70 & 0.60 & 14.1 & 35.8 & 10.8 & 0.80 & 1.60 & 49.0 & 24.3 & $73 \cdot 3$ & 67 \\
\hline & $29-<48$ & 2Btg1 & 6.4 & 5.4 & 2.50 & 7.40 & 0.70 & 10.0 & 56.8 & 15.8 & 1.00 & 1.40 & 75.1 & 24.3 & $99 \cdot 3$ & 76 \\
\hline & $48-<70$ & 2Btg2 & 6.6 & 5.6 & 3.10 & 6.20 & 0.00 & 0.00 & 44.0 & 11.8 & 0.90 & 1.20 & 57.9 & 22.4 & 80.3 & 72 \\
\hline & $70-<90$ & 3BCtg1 & 7.6 & 6.6 & 6.80 & 7.00 & 0.00 & 0.00 & 87.8 & 19.9 & 0.90 & 2.10 & 110 & 7.50 & 118 & 94 \\
\hline & $>90$ & 3BCtg2 & 8.0 & 7.2 & 37.4 & 5.90 & 0.00 & 0.00 & 137 & 26.2 & 0.90 & 1.70 & 166 & 3.70 & 170 & 8 \\
\hline \multirow{5}{*}{$\mathrm{P}_{5}$} & $0-<15$ & $\mathrm{AB}$ & $7 \cdot 9$ & $7 \cdot 3$ & 0.00 & 18.7 & 1.80 & 10.3 & 69.8 & 15.9 & 1.20 & 2.50 & 89.3 & 20.8 & 110 & 81 \\
\hline & $15^{-<30}$ & Btg1 & 8.0 & $7 \cdot 5$ & 0.00 & 0.90 & 1.50 & 0.60 & 130 & $27 \cdot 3$ & 1.10 & 2.00 & 161 & 12.5 & 173 & 93 \\
\hline & $30-<60$ & 2Btg2 & 8.2 & $7 \cdot 5$ & 31.2 & 5.20 & 1.10 & 4.70 & 71.6 & 19.3 & 1.20 & 2.20 & 94.4 & 8.30 & 102 & 92 \\
\hline & $60-<90$ & 2BCtg & 8.4 & 7.6 & 34.9 & 3.00 & 0.60 & 5.00 & 156 & 28.8 & 1.40 & 2.40 & 188 & 4.20 & 193 & 98 \\
\hline & $0-<8$ & A & $5 \cdot 3$ & $3 \cdot 3$ & n.d. & 25.0 & 2.40 & 10.4 & 13.4 & 8.20 & 9.30 & 5.40 & 36.3 & 154 & 190 & 19 \\
\hline \multirow{6}{*}{ P6 } & $8-<21$ & $2 \mathrm{AB}$ & 5.4 & 3.8 & n.d. & 10.9 & 2.60 & & 34.8 & 12.7 & 8.20 & 3.20 & 58.8 & 62.5 & 121 & 48 \\
\hline & $21-<31$ & 2Bt1 & 5.8 & 4.1 & n.d. & 8.80 & 2.30 & 3.80 & 41.9 & 11.3 & 7.90 & 2.60 & 63.8 & 45.8 & 109 & 58 \\
\hline & & 2Bt2 & 6.1 & 4.7 & n.d. & 29.0 & 0.90 & 30.7 & 6.7 & 19.0 & 2.80 & 2.30 & 30.8 & $33 \cdot 3$ & 64.1 & 48 \\
\hline & $46-<58$ & $3 \mathrm{BtC} 1$ & 5.9 & 4.7 & n.d. & 31.7 & 2.50 & 12.6 & 30.8 & 12.6 & 2.60 & 2.00 & 48.0 & 29.2 & 77.2 & 62 \\
\hline & $58-<80$ & 3BtC2 & 5.8 & 4.8 & n.d. & 36.8 & 1.00 & 38.7 & 57.5 & 14.8 & 9.70 & 2.40 & 84.4 & 25.0 & 109 & 77 \\
\hline & $80-<113$ & $3 \mathrm{C}$ & 6.7 & 5.9 & 9.87 & 39.6 & 3.00 & 13.3 & 90.0 & 14.1 & 2.80 & 2.10 & 109 & 16.7 & 125 & 87 \\
\hline \multirow{5}{*}{ P7 } & $0-<10$ & $\mathrm{Ah}$ & 6.2 & 5.1 & & 18.5 & 4.30 & 4.40 & 219 & 21.1 & 1.60 & 4.70 & 247 & 54.5 & 301 & 82 \\
\hline & $10-<22$ & $\mathrm{Bt}$ & $7 \cdot 3$ & 4.5 & 0.00 & 2.70 & 0.60 & 4.40 & 156 & 25.0 & 2.10 & 5.20 & 188 & 26.8 & 215 & 88 \\
\hline & $22-<46$ & Btg1 & 8.2 & 6.0 & 0.00 & 2.30 & 0.50 & 4.50 & 159 & 25.0 & 2.20 & 4.80 & 191 & 14.3 & 205 & 93 \\
\hline & $46-<75$ & 2Btg2 & 8.3 & 6.4 & 0.00 & 1.10 & 0.60 & 1.70 & 191 & 30.0 & 2.10 & 5.60 & 229 & 9.80 & 239 & 96 \\
\hline & $75^{-<115}$ & 2BCtg & 8.8 & 7.4 & 113 & 0.60 & 0.40 & 1.60 & 156 & 20.9 & 1.50 & 7.20 & 186 & 6.30 & 192 & 97 \\
\hline
\end{tabular}

Explanations: TOC-total organic carbon; TN-total nitrogen; C:N-the total organic carbon and nitrogen ratio; $\mathrm{Ca}^{2+}$, $\mathrm{Mg}{ }^{2+}, \mathrm{Na}^{+}, \mathrm{K}^{+}-$exchangeable cations; TEB-total exchangeable bases; TPA-total potential acidity'; CEC-cation exchange capacity; BS-base saturation; n.d.-not determined.

crumb type of microstructure down to depths of 40 $\mathrm{cm}$ was noted, with compound-packing and channel void types, suitable for such microstructures (Table 5). The coarse:fine (c:f)related distribution was porphyric, showing a different ratio (size limit) of fine and coarse units (Table 5; Figure 4c, e; Figure 5a). The micromass within the upper part of the soils $\mathrm{P}_{1}$ and $\mathrm{P}_{3}$ partially represented the undifferentiated b-fabric, whereas the upper part of $\mathrm{P} 2$ showed porostriated, granostriated and speckled b-fabric types. Within the horizons ACk and $2 \mathrm{Ck} 1$ of P1 (Figure $3 \mathrm{~d}, \mathrm{f}$ ) and
2BkC, $2 \mathrm{Ck} 1$ of $\mathrm{P} 2$ (Figure $4 \mathrm{~d}, \mathrm{f}$ ), as well as $2 \mathrm{BCk}$ and 2BCkt1 of $\mathrm{P}_{3}$ (Figure $5 \mathrm{~b}, \mathrm{~d}$ ) in part, the crystallitic type of b-fabric was noted. Furthermore, porostraited (Figure 5f), granostriated and speckled (Figure $5 \mathrm{~b}, \mathrm{f}$ ) types of b-fabric were distinguished in the middle and lower parts of $\mathrm{P}_{3}$ (Table 5).

In soil $\mathrm{P} 1$ at depths from the surface to $65 \mathrm{~cm}$, secondary calcium carbonate was noted, in the form of typic, geodic and concentric $\mathrm{CaCO}_{3}$ nodules (Figure $3 \mathrm{~d}$ ) and channel calcitic hypocoatings (Figure 3f). Otherwise, in P2 secondary calcium 

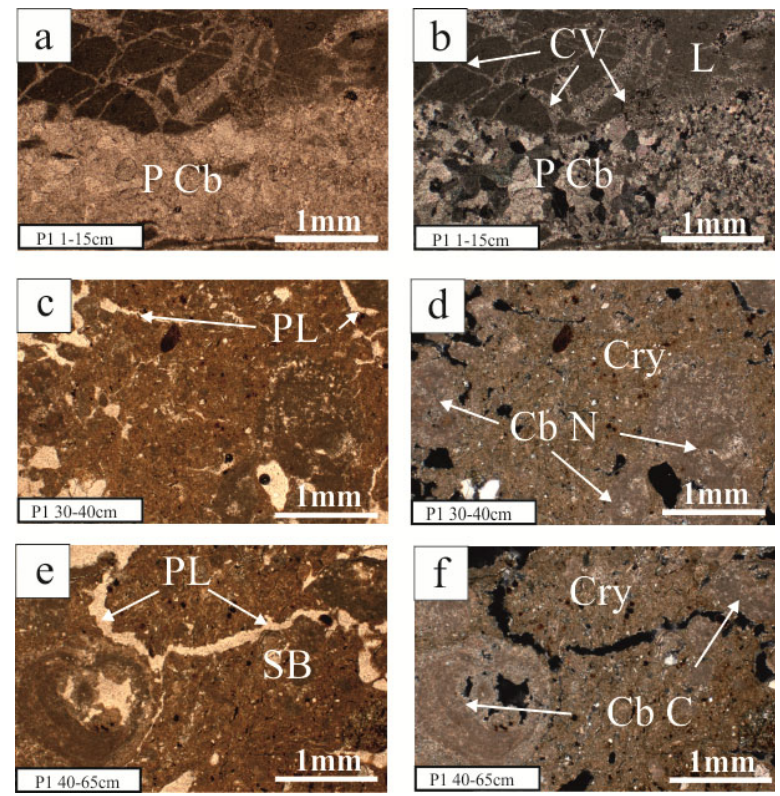

Figure 3 Microphotographs of soil thin sections from P1. Explanations: $(\mathrm{a}, \mathrm{b})$ : $(\mathrm{P} \mathrm{Cb})$ - primary calcium carbonate; (L) - limestone, $(\mathrm{CV})$ - calcite veins; (c, d): (PL) - planar type of voids, (Cry) - crystallitic b-fabric, $(\mathrm{Cb} \mathrm{N})$ - calcium carbonate nodules (concentric); (e, f): (SB) - subangular blocky microstructure, (PL) planar type of voids, (Cry) - crystallitic b-fabric, (Cb C) - channel calcitic hypocoatings. Bar length $=1 \mathrm{~mm}$. a, c, e - PPL microphotographs; b, d, f - XPL microphotographs.

carbonate occurred only at depths from 60 to 110 $\mathrm{cm}$ in the form of geodic (Figure $4 \mathrm{f}$ ) and typic (Figure $4 \mathrm{~d}$ ) $\mathrm{CaCO}_{3}$ nodules. The presence of secondary carbonate accumulation in $\mathrm{P}_{3}$ was visible at depths from 20 to $90 \mathrm{~cm}$ forming a dense microsparitic matrix (Figure 5 d; Table 5).

Within the whole of the $\mathrm{P}_{1}, \mathrm{P}_{2}$ and $\mathrm{P}_{3}$ profiles, the iron-manganese impregnations were seen (e.g. Figure 4a, c, e; Figure 5e). Additionally, rounded, diffused, iron-manganese orthic nodules were noted within the Ahk1 and $2 \mathrm{Ck} 1$ horizons of $\mathrm{P} 1$ and upper horizons of $\mathrm{P}_{3}$. In terms of other pedofeatures, fragments of infillings of illuvial clay and typic clay coatings were noted in P2 (Figure 4b) and $\mathrm{P}_{3}$ (Figure $5 \mathrm{f}$ ) in the middle and lower parts of the soil profiles, respectively (Table 5).

Organ and tissue residues as well as fragments of organic fine material were present down to 40 $\mathrm{cm}$ in P1. Within P2, organ (Figure 4e) and tissue residue occurred in whole profile. The soil $\mathrm{P}_{3}$ was characterized by the occurrence of organ residues in every horizon and tissue residues in A horizons (Table 5).

Within P1 and P2, limestone was visible,
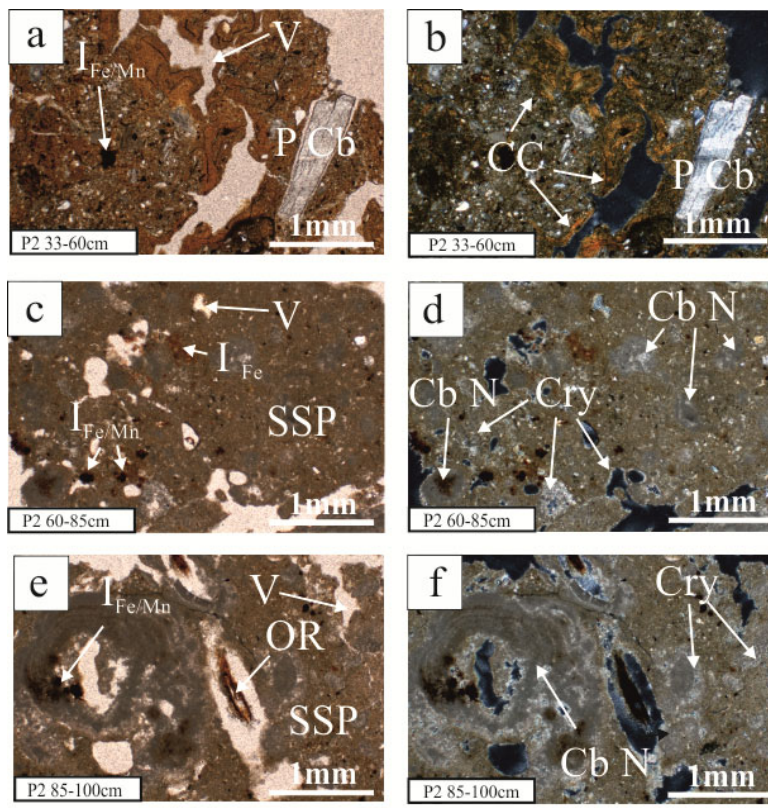

Figure 4 Microphotographs of soil thin sections from P2. Explanations: (a, b): $\left(\mathrm{I}_{\mathrm{Fe} / \mathrm{Mn}}\right)-\mathrm{Fe} / \mathrm{Mn}$ impregnations, ( $\mathrm{P} \mathrm{Cb})$ - primary calcium carbonate, (V) - vughs type of voids, (CC) - typic clay coatings; (c, d): $\left(\mathrm{I}_{\mathrm{Fe} / \mathrm{Mn}}\right)-\mathrm{Fe} / \mathrm{Mn}$ impregnations, $\left(\mathrm{I}_{\mathrm{Fe}}\right)-\mathrm{Fe}$ impregnations, (V) - vughs type of voids, (SSP) single-spaced porphyric type of c:f related distribution; $(\mathrm{Cb} \mathrm{N})$ - typic carbonate nodules, (Cry) - crystallitic bfabric; (e, f): ( $\left.\mathrm{I}_{\mathrm{Fe} / \mathrm{Mn}}\right)$ - Fe/Mn impregnations, (OR) organ residues, (SSP) - single-spaced porphyric type of c:f related distribution, (V) - vughs type of voids, (Cry) - crystallitic b-fabric, $(\mathrm{Cb} \mathrm{N})$ - geodic carbonate nodules. Bar length $=1 \mathrm{~mm}$. a, c, e - PPL microphotographs; b, d, f - XPL microphotographs.

sometimes with calcite veins (Figure $3 \mathrm{~b}$ ). In the surface horizon of $\mathrm{P}_{3}$, the fragments of shale occurred. Moreover, quartz, plagioclase and clay minerals were also seen in the studied profiles (Table 5).

\subsection{Group 2: Enrichment in calcium carbonate was identified in the $B$ (AB) and $\mathrm{C}$ horizons}

\subsubsection{Morphological characteristics, chemical properties and texture}

Profiles $\mathrm{P}_{4}$ and $\mathrm{P}_{5}$ were examples of primary calcium carbonates enriching the middle and lower part of soil profiles (Table 1, Figure 2). Both profiles were classified as Stagnosols (Table 1). Soils $\mathrm{P}_{4}$ and $\mathrm{P}_{5}$ were characterized by the occurrence of the mosaic of colours typical for stagnic properties. In some places, the presence of black manganese concentrations and iron mottles 

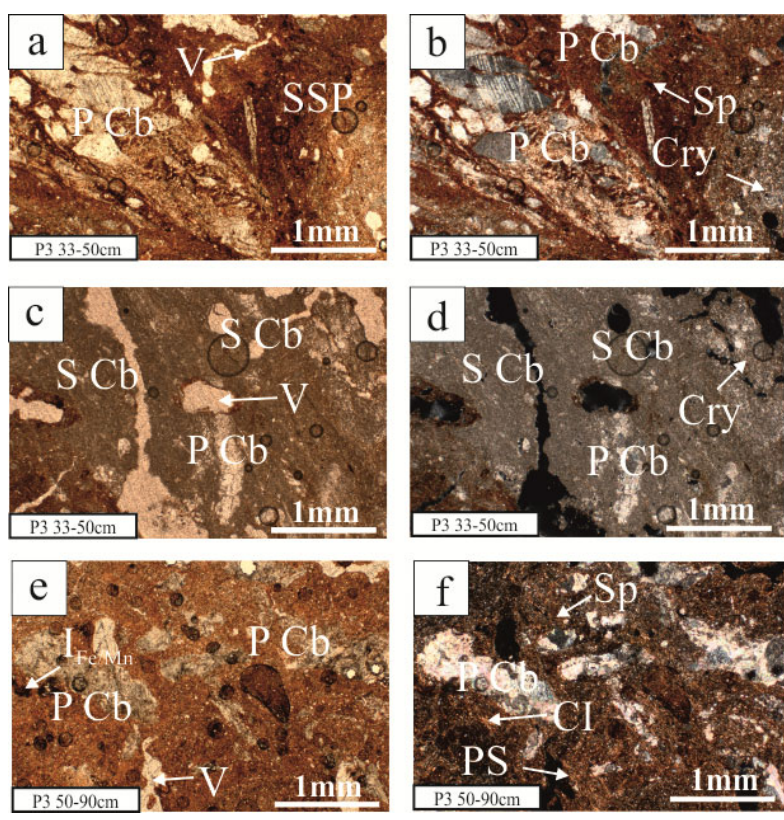

Figure 5 Microphotographs of soil thin sections from P3. Explanations: $(\mathrm{a}, \mathrm{b})$ : $(\mathrm{P} \mathrm{Cb})$ - primary calcium carbonate, (V) - vughs type of voids, (SSP) - singlespaced porphyric type of $\mathrm{c}:$ f related distribution, $(\mathrm{Sp})-$ speckled b-fabric, (Cry) - crystallitic b-fabric; (c, d): (P $\mathrm{Cb})$ - primary calcium carbonate, (S Cb) accumulation of secondary carbonate, $(\mathrm{V})$ - vughs type of voids, (Cry) - crystallitic b-fabric; (e, f): (P Cb) primary calcium carbonate, $\left(\mathrm{I}_{\mathrm{Fe} / \mathrm{Mn}}\right)-\mathrm{Fe} / \mathrm{Mn}$ impregnations, (V) - vughs type of voids, (Sp) speckled b-fabric, (PS) - porostriated b-fabric, (CI) infillings of illuvial clay. Bar length $=1 \mathrm{~mm}$. a, c, e PPL microphotographs; b, d, f - XPL microphotographs.

was identified. The coarse fragment concentrations ranged from 5 to $30 \%\left(\mathrm{P}_{4}\right)$ and from 15 to $60 \%\left(\mathrm{P}_{5}\right)$ and generally increased downward soil profile (Table 2).

Considering the grain size distribution of $\mathrm{P} 4$, the silt fraction predominated in every horizon, reaching values higher than 50\% (fine silt and coarse silt in total, Table 3), allowing the classification of the fraction group as silty loam to depths down to $70 \mathrm{~cm}$ and as silty clay loam below $70 \mathrm{~cm}$. The highest silt fraction was noted in the Ap and $\mathrm{ABw}$ horizons, where the silt content ranged between 55 and 69\%. In the lowest horizons (3BCtg1 and $3 \mathrm{BCtg} 2)$, the clay fraction increased at the expense of the silt fraction (Table 3). Similarly, the silt content was also the highest in $\mathrm{P}_{5}$, especially in the upper horizons; for example in $A B$, the fine silt and coarse silt in total was $64 \%$. Below $15 \mathrm{~cm}$, the content of clay fraction increased, allowing classification as silty clay loam (Table 3 ).
Calcium carbonate in $\mathrm{P}_{4}$ occurred at depths from $18 \mathrm{~cm}$ to more than $90 \mathrm{~cm}$ and ranged from 2.20 to $37.5 \mathrm{~g} \cdot \mathrm{kg}^{-1}$. Calcium carbonate in $\mathrm{P}_{5}$ occurred from $30 \mathrm{~cm}$ to $90 \mathrm{~cm}$, indicating a more homogenous pattern, ranging from 31.2 to 34.9 $\mathrm{g} \cdot \mathrm{kg}^{-1}$. The $\mathrm{P}_{5}$ soil had a higher percentage content of base saturation, compared to profile $\mathrm{P} 4$. However, $\mathrm{pH}$ values were very similar in both profiles and ranged from 6.1 to 8.4 in $\mathrm{H}_{2} \mathrm{O}$ and from 5.1 to 7.6 in a $\mathrm{KCl}$ solution (Table 4 ).

\subsubsection{Micromorphological characteristics \\ soil}

In soils $\mathrm{P}_{4}$ and $\mathrm{P}_{5}$, the subangular blocky (Figure 7e) and vughy microstructure as well as planar (Figure 7e) and vughs (Figure 7a, c) type of voids were recognized in almost every horizon (Table 5). In the Ap and ABw horizons of soil $\mathrm{P}_{4}$ and the $\mathrm{AB}$ horizon of $\mathrm{P}_{5}$, the crumb microstructure and compound-packing and channel void types were identified (Figure 6a). The related distribution pattern, the porphyric type, was seen, with different fine and coarse ratios in both profiles (Table 5A; Figure 6c, e; Figure 7a). The soils showed a remarkable homogeneity in terms of b-fabric character. The $\mathrm{Ap}$ and $\mathrm{ABt}$ horizons of $\mathrm{P}_{4}$ represented a partially undifferentiated type of b-fabric. Below, speckled (Figure 6d, f) as well as granostriated (Figure 6d) types of b-fabric were recognized. In the case of $\mathrm{P}_{5}$, the partially undifferentiated and speckled (Figure $7 \mathrm{~b}, \mathrm{~d}, \mathrm{f}$ ) types of b-fabric dominated at depths from o to $60 \mathrm{~cm}$; below $60 \mathrm{~cm}$ only the speckled type of b-fabric was recognized (Table $5 \mathrm{~A}$ ).

No secondary carbonates were recognized in $\mathrm{P}_{4}$ and $\mathrm{P}_{5}$. However, many clay secondary forms such as infillings of illuvial clay and typic clay coatings were seen (Table 5; Figure 6f; Figure 7d). Within the pedofeatures, iron-manganese impregnations were noted in every horizon (Figure $6 c$; Figure $7 b, f)$, together with rounded, diffused, iron-manganese orthic nodules in the upper ( $\left.\mathrm{P}_{4}\right)$ and middle ( $\left.\mathrm{P}_{5}\right)$ parts of soil profile.

Organ and tissue residues occurred in almost all upper and middle horizons of $\mathrm{P}_{4}$ and $\mathrm{P}_{5}$. In terms of rock fragments, sandstone and shale (Figure 6c, d) were present in every horizon (Table 5). Focusing on the mineral arrangement, quartz was present within the whole solum (e.g. Figure 6b); however, plagioclase was indicated in the 
J. Mt. Sci. (2020) 17(6): 1210-1322

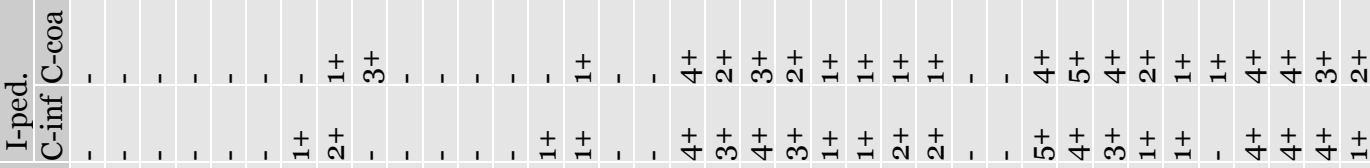
N

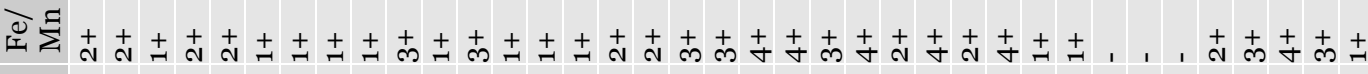

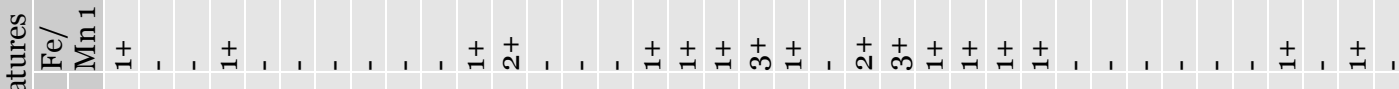
ฐ

$\stackrel{+}{+} \stackrel{+}{+}$

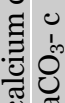

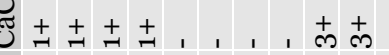

ఫึ

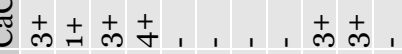

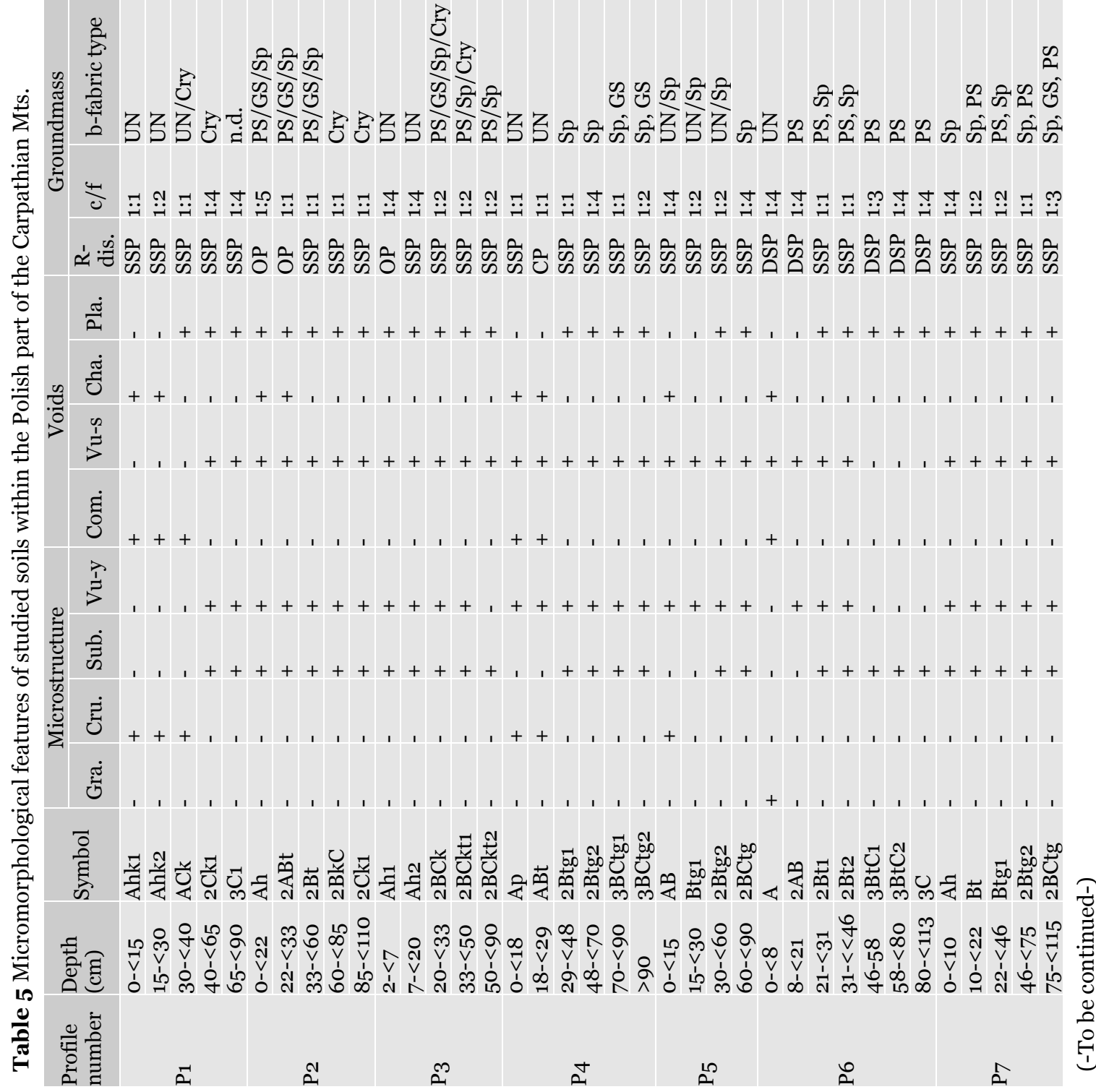


Table 5 Micromorphological features of studied soils within the Polish part of the Carpathian Mts. (-Continued-)

\begin{tabular}{|c|c|c|c|c|c|c|c|c|c|c|c|c|c|c|}
\hline \multirow{2}{*}{$\begin{array}{l}\text { Profile } \\
\text { number }\end{array}$} & \multirow{2}{*}{$\begin{array}{l}\text { Depth } \\
\text { (cm) }\end{array}$} & \multirow{2}{*}{ Symbol } & \multicolumn{4}{|c|}{ Organic matter } & \multicolumn{4}{|c|}{ Mineral grains composition } & \multicolumn{4}{|c|}{ Rock fragments } \\
\hline & & & O- res & T-res & $\mathrm{O}-\mathrm{fm}$ & Ch-c & $\mathrm{P}-\mathrm{cc}$ & Qua. & Pla. & Cla-m & Limestone & Lim- cv & Sandstone & Shale \\
\hline \multirow{5}{*}{ P1 } & $0-<15$ & Ahk1 & + & $+\quad$ & + & - & + & + & + & - & + & + & + & - \\
\hline & $15^{-<}<30$ & Ahk2 & + & + & + & - & + & + & + & - & + & + & - & - \\
\hline & $30-<40$ & $\mathrm{ACk}$ & + & + & + & - & + & + & + & - & + & - & + & - \\
\hline & $40-<65$ & 2Ck1 & - & - & - & - & + & + & + & - & + & + & - & - \\
\hline & $65-<90$ & $3 \mathrm{C} 1$ & - & - & - & - & + & + & + & - & + & - & - & - \\
\hline \multirow{5}{*}{$\mathrm{P} 2$} & $0-<22$ & $\mathrm{Ah}$ & + & + & - & - & + & + & - & - & - & - & - & - \\
\hline & $22-<33$ & $2 \mathrm{ABt}$ & + & + & - & - & + & + & - & - & + & - & - & - \\
\hline & $33^{-<60}$ & $2 \mathrm{Bt}$ & + & + & - & - & + & + & - & + & - & - & - & - \\
\hline & $60-<85$ & 2BkC & + & + & - & - & + & + & + & + & - & - & - & - \\
\hline & $85^{-<110}$ & 2Ck1 & + & + & - & - & + & + & + & + & - & + & - & - \\
\hline \multirow{5}{*}{$P_{3}$} & $2-<7$ & Ah1 & + & + & - & - & + & - & - & + & - & - & + & + \\
\hline & $7-<20$ & Ah2 & + & + & - & - & + & - & - & - & - & - & - & + \\
\hline & $20-<33$ & 2BCk & + & - & - & - & + & - & - & - & - & - & - & - \\
\hline & $33^{-<50}$ & 2BCkt1 & + & - & - & - & + & - & - & - & - & - & - & - \\
\hline & $50-<90$ & 2BCkt2 & + & - & - & - & + & - & - & - & - & - & - & - \\
\hline \multirow{6}{*}{$\mathrm{P}_{4}$} & $0-<18$ & Ap & + & - & - & - & - & + & - & - & - & - & + & - \\
\hline & $18-<29$ & $\mathrm{ABt}$ & - & + & - & - & - & + & - & - & - & - & + & + \\
\hline & $29-<48$ & 2Btg1 & + & + & - & - & - & + & - & - & - & - & + & + \\
\hline & $48-<70$ & 2Btg2 & + & + & - & - & - & + & - & - & - & - & + & - \\
\hline & $70-<90$ & 3BCtg1 & + & + & - & - & - & + & - & - & - & - & + & - \\
\hline & $>90$ & 3BCtg2 & - & - & + & - & + & + & - & - & - & - & + & - \\
\hline \multirow{4}{*}{$\mathrm{P}_{5}$} & $0-<15$ & $\mathrm{AB}$ & + & + & - & - & - & + & - & - & - & - & + & + \\
\hline & $15^{-<30}$ & Btg1 & + & - & - & - & - & + & - & - & - & - & + & + \\
\hline & $30-<60$ & 2Btg2 & - & + & - & - & + & + & - & - & - & - & + & + \\
\hline & $60-<90$ & 2BCtg & - & - & - & - & + & + & - & - & - & - & + & + \\
\hline \multirow{7}{*}{ P6 } & $0-<8$ & A & + & + & - & - & - & + & - & + & - & - & - & + \\
\hline & $8-<21$ & $2 \mathrm{AB}$ & + & + & - & - & - & + & - & + & - & - & - & + \\
\hline & $21-<31$ & 2Bt1 & + & + & + & - & - & + & - & + & - & - & - & + \\
\hline & $31-<<46$ & $2 \mathrm{Bt} 2$ & - & - & - & - & - & + & - & + & - & - & - & + \\
\hline & $46-58$ & $3 \mathrm{BtC} 1$ & - & + & - & - & - & + & - & + & - & - & - & + \\
\hline & $58-<80$ & $3 \mathrm{BtC2}$ & - & - & - & - & - & + & - & + & - & - & - & + \\
\hline & $80-<113$ & $3 \mathrm{C}$ & - & - & - & - & - & + & - & + & - & - & - & + \\
\hline \multirow{5}{*}{$\mathrm{P}_{7}$} & $0-<10$ & $\mathrm{Ah}$ & + & + & + & + & - & + & - & - & - & - & + & - \\
\hline & $10-<22$ & $\mathrm{Bt}$ & - & + & + & - & - & + & - & - & - & - & - & - \\
\hline & $22-<46$ & Btg1 & - & - & + & - & - & + & - & - & - & - & - & - \\
\hline & $46-<75$ & 2Btg2 & - & - & + & - & - & + & - & - & - & - & - & - \\
\hline & $75^{-<115}$ & 2BCtg & - & + & + & - & + & + & - & - & - & - & + & - \\
\hline
\end{tabular}

Explanations: Gra. -Granular; Cru. -Crumb; Sub. - Subangular blocky; Vu-y - Vughy; Com.-Compound packing; Vu-s -Vughs; Cha.-Channels; Pla.-Planes; R-dis.-Related distribution; $\mathrm{CaCO}_{3}-\mathrm{n}-\mathrm{CaCO}_{3}$ nodules; $\mathrm{CaCO}_{3}$-c- $\mathrm{CaCO}_{3}$ coatings; $\mathrm{S}-\mathrm{CaCO}_{3}-$ secondary $\mathrm{CaCO}_{3}$ accumulation; $\mathrm{Fe} / \mathrm{Mn} 1-\mathrm{Fe} / \mathrm{Mn}$ nodules; $\mathrm{Fe} / \mathrm{Mn} 2-\mathrm{Fe} / \mathrm{Mn}$ impregnations; I-ped.-Illuvial pedofeatures; C- inf-Clay infillings; C-coa-Clay coatings; O- res-Organ residues; T-res-Tissue residues; O-fm-Organic fine material; Ch-c-Charcoal; P-cc-Primary calcium carbonate; Qua.Quartz; Pla.-Plagioclase; Cla-m -Clay minerals; Lim-cv -Limestone with calcite veins.

Type of c/f related distribution: CP - close porphyric, SSP - single spaced porphyric, DSP - double spaced porphyric, OP - open porphyric. Type of b-fabric: UN - undifferentiated, Cry - crystallitic, Sp - speckled, PS porostriated, GS - granostriated.

The quantity of pedofeatures: $1: 0 \%-<2 \%, 2: 2 \%-<5 \%, 3: 5 \%-<10 \%, 4: 10 \%-<20 \%, 5:>20 \%$.

horizon only at depths down to $48 \mathrm{~cm}$ (Table 5). In soils $\mathrm{P}_{4}$ and $\mathrm{P}_{5}$, primary carbonate minerals were found only within the middle and lower horizons.

\subsection{Group 3: Calcium carbonate only occurred in the C horizons}

\subsubsection{Morphological characteristics, chemical properties and texture}

Calcium carbonate occurred only in the $3 \mathrm{C}$ and 2BCtg horizons in soils $\mathrm{P} 6$ and $\mathrm{P} 7$, respectively, both classified as Luvisols. Within the whole solum, subangular/angular ( $\mathrm{P} 6)$ and angular $\left(\mathrm{P}_{7}\right)$ rock fragments occurred, and their content increased 

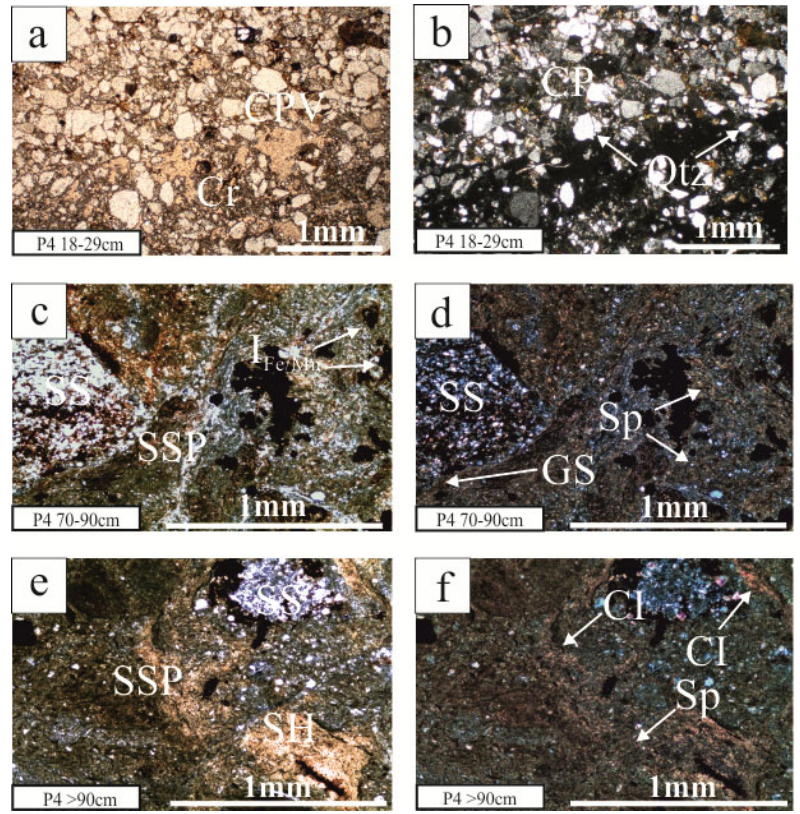

Figure 6 Microphotographs of soil thin sections from P4. Explanations: $(\mathrm{a}, \mathrm{b})$ : (CPV) - compound packing voids, (Cr) - crumb microstructure, (Qtz) - quartz, (CP) - close porphyric type of c:f related distribution; (c, d): (SS) - sandstone, (SSP) - single-spaced porphyric type of c:f related distribution, $\left(\mathrm{I}_{\mathrm{Fe} / \mathrm{Mn}}\right)$ Fe/Mn impregnations, (Sp) - speckled b-fabric, (GS) granostriated b-fabric; (e, f): (SS) - sandstone, (SSP) single-spaced porphyric type of c:f related distribution; (SH) - shale, (CI) - infillings of illuvial clay, (Sp) speckled b-fabric. Bar length $=1 \mathrm{~mm}$. a, c, e - PPL microphotographs; b, d, f - XPL microphotographs.

down the soil profile (Table 2). However, the soil profiles demonstrated different contents of coarse fragments: within soil P6, coarse fragments ranged from $5 \%$ to $90 \%$ and within soil $\mathrm{P} 7$, merely from $5 \%$ to $10 \%$ (Table 2).

With respect to the size grain distribution of P6, the total quantity of sand ( $60 \%)$ dominated in A horizons; this sandy loam texture of the topsoil allowed the foreign nature of this horizon to be diagnosed. In lower horizons, the content of sand decreased, accompanied by an increasing silt and clay fraction, which reached up to $50 \%$ and $30 \%$, respectively. The content of fine and coarse silt and clay varied. At depths of 8 to $46 \mathrm{~cm}$, a silty loam texture was seen; below this, in sequence silty clay loam, clay loam and loam were identified. Such an arrangement suggests stratification within the profile (Table 3). Soil $\mathrm{P}_{7}$ showed a different pattern in terms of texture. At depths down to $22 \mathrm{~cm}$, in the horizons $\mathrm{Ah}$ and $\mathrm{Bt}$ the clay fraction prevailed (31\%-39\%, Table 3) giving them a clay loam texture. Below, the increase of the silt fraction was
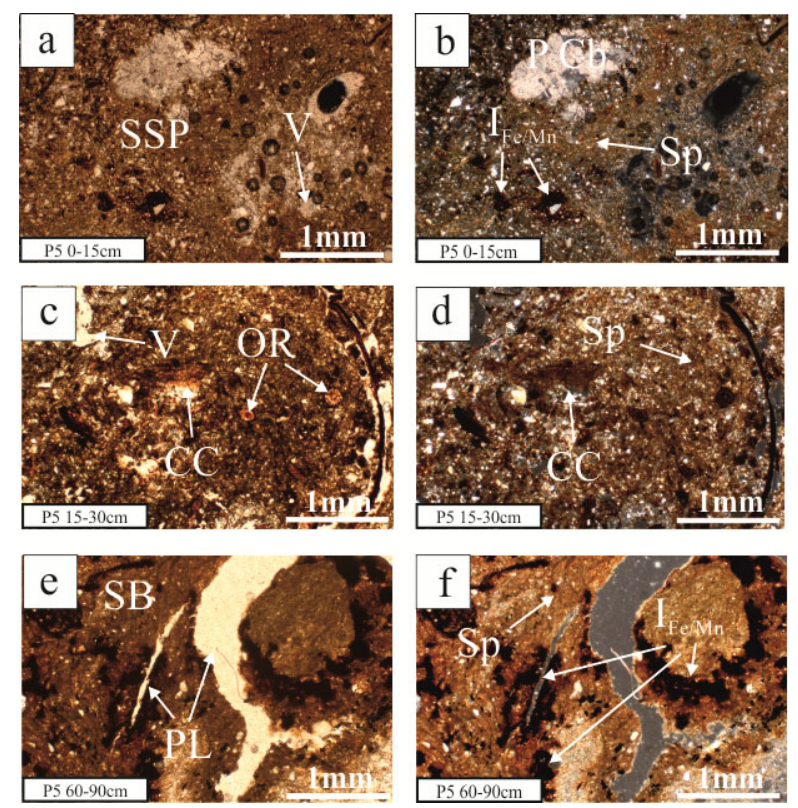

Figure 7 Microphotographs of soil thin sections from P5.Explanations: (a, b): (V) - vughs type of voids, (SSP) - single-spaced porphyric type of related distribution, ( $\mathrm{P} \mathrm{Cb}$ ) - primary calcium carbonate, $\left(\mathrm{I}_{\mathrm{Fe} / \mathrm{Mn}}\right)$ - Fe/Mn impregnations, $(\mathrm{Sp})$ - speckled bfabric; (c, d): (V) - vughs type of voids, (OR) - organ residues, (CC) - typic clay coatings, (Sp) - speckled bfabric; (e, f): (SB) - subangular blocky microstructure, (PL) - planar type of voids, (Sp) - speckled b-fabric, $\left(\mathrm{I}_{\mathrm{Fe} / \mathrm{Mn}}\right)-\mathrm{Fe} / \mathrm{Mn}$ impregnations. Bar length $=1 \mathrm{~mm}$. a, c, e - PPL microphotographs; b, d, f - XPL microphotographs.

noticeable. Often the silt fraction reached more than $50 \%$, and silt clay loam and silt loam were seen (Table 3). The size grain distribution suggested a high heterogeneity of $\mathrm{P} 7$.

The calcium carbonate levels in $\mathrm{P} 6$ and $\mathrm{P} 7$ soils were 9.83 and $113 \mathrm{~g} \cdot \mathrm{kg}^{-1}$ in the $3 \mathrm{C}$ and $2 \mathrm{BCtg}$ horizons, respectively (Table 4). Nonetheless, soil $\mathrm{P}_{7}$ was characterized by higher $\mathrm{pH}$ values and a higher base saturation compared to profile P6 (Table 4). A very high variability of TOC was noted within the whole profile of P6. The TOC values in P6 did not indicate any clear trend and ranged from 8.80 to $39.6 \mathrm{~g} \cdot \mathrm{kg}^{-1}$ (Table 4). Atypically, the highest values of TOC were in horizon $3 \mathrm{C}$, which might evidence a level of high mixing of the soil material (Table 4).

\subsubsection{Micromorphological characteristics}

soil

The A horizon of P6 showed a granular microstructure with compound packing and channel voids. The horizon $2 \mathrm{AB}$ represented a 

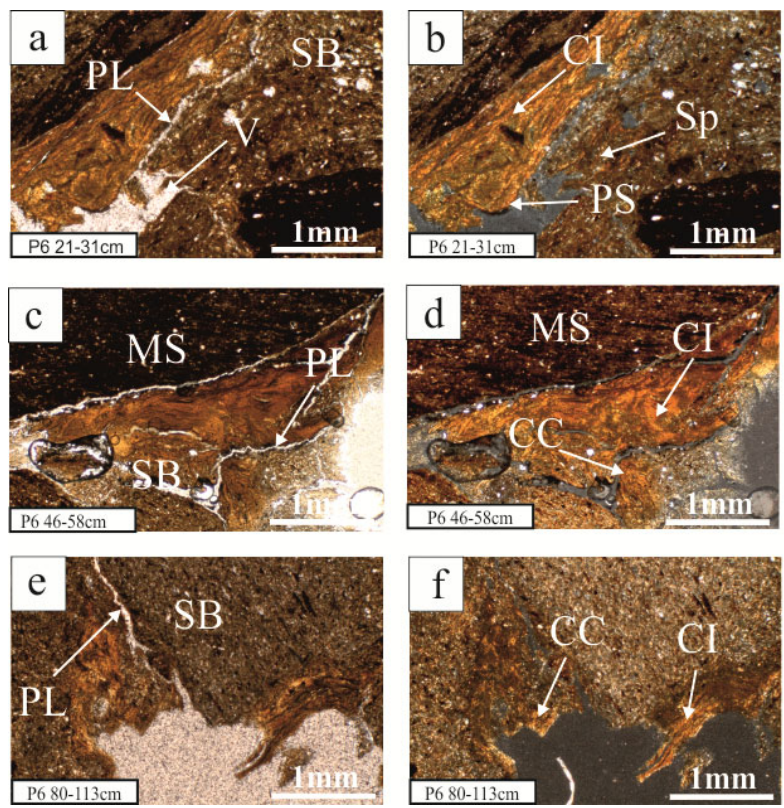

Figure 8 Microphotographs of soil thin sections from P6. Explanations: (a, b): (SB) - subangular blocky microstructure, (PL) - planar type of voids, (V) - vughs type of voids, (PS) - porostriated b-fabric, (Sp) speckled b-fabric, (CI) - infillings of illuvial clay; (c, d): (MS) - menilite shale, (SB) - subangular blocky microstructure, (PL) - planar type of voids, (CC) typic clay coatings, (CI) - infillings of illuvial clay; (e, f): (PL) - planar type of voids, (SB) - subangular blocky microstructure, (CC) - typic clay coatings, (CI) - infillings of illuvial clay. Bar length $=1 \mathrm{~mm}$. a, c, e PPL microphotographs; b, d, f - XPL microphotographs.

vughy microstructure with vughs types of voids. All horizons lying below these showed a subangular blocky microstructure and a planar void type (Figure 8a, c, e). Profile $\mathrm{P} 7$ was homogenous in terms of microstructure and voids (Table 5); only subangular blocky and vughy microstructure together with planar and vughs types of voids were recognized (Figure 9a, e). Similar to the other studied soils, $\mathrm{P} 6$ and $\mathrm{P} 7$ indicated a porphyric type of related distribution pattern, with various size limits of c:f (Figure 9a, c). Besides, the partially undifferentiated type of b-fabric in A horizon of P6. Usually, mainly porostriated (Figure 8b; Figure 9f) and partially speckled (Figure 8b; Figure $9 \mathrm{~b}$ ) types of b-fabric were noted in soils $\mathrm{P} 6$ and $\mathrm{P} 7$.

Within P6 and P7, no secondary calcium carbonate was found. Moreover, clay pedofeatures were seen mostly in the form of fragments of infillings of illuvial clay as well as typic and crescent types of clay coatings (Figure 8b, d, f; Figure $9 \mathrm{~b}, \mathrm{~d}, \mathrm{f}$ ), which were unevenly distributed
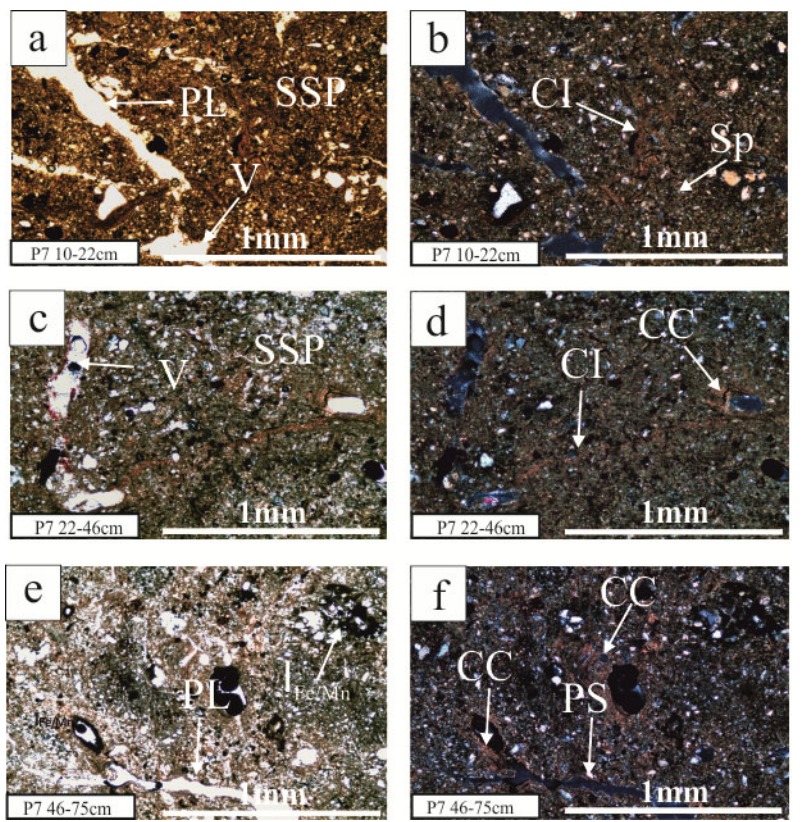

Figure 9 Microphotographs of soil thin sections from P7.Explanations: (a, b): (PL) - planar type of voids, (V) - vughs type of voids, (SSP) - single-spaced porphyric type of c:f related distribution, (CI) - infillings of illuvial clay, (Sp) - speckled b-fabric; (c, d): (V) vughs type of voids, (SSP) - single-spaced porphyric type of c:f related distribution, (CI) - infillings of illuvial clay, (CC) - crescent clay coatings; (e, f): (PL) planar type of voids, ( $\left.\mathrm{I}_{\mathrm{Fe} / \mathrm{Mn}}\right)-\mathrm{Fe} / \mathrm{Mn}$ impregnations, (CC) - crescent clay coatings, (PS) - porostriated bfabric. Bar length $=1 \mathrm{~mm}$. a, c, e - PPL microphotographs; b, d, f - XPL microphotographs.

within the solum. The rounded, diffused, ironmanganese orthic nodules were recognized some horizons, and however more often the ironmanganese impregnations were identified (Figure 9e).

Within soil P6 mostly organ and tissue residues were visible in the upper part of the soil profile. Organic fine material occurred within the whole profile of $\mathrm{P}_{7}$, with plant organ and tissue residues rarely seen, only in the Ah horizon. Only quartz and fragments of sandstone were recognized within soil $\mathrm{P} 7$ (Table 5). In profile P6, plagioclase and clay minerals and fragments of menilite shales (Figure 8c, d) were also seen.

\section{Discussion}

3.1 The occurrence and distribution of microfeatures in heterogeneous soils located on slopes 
The soil material had been relocated on slopes to various degrees and intensity, which was evident in the current occurrence and arrangement of micromorphological forms, e.g. the various distribution of coarse fragments, subangular and angular shape and elongated position of coarse fragments, the changes of c:f size limit in soil matrix and sudden changes of b-fabric within the solum (Tables 2 and 5A). Moreover, the presence of fragments of pedofeatures evidenced activity of slope processes (see Section 4.2). Such a heterogenic character and organization of soil microfeatures within soils located on slopes have been often noted in various studies, e.g. Bertran and Texier (1999); Bertran et al. (1997); Harris (1998); Kacprzak and Żyła (2006); Kehl et al. (2018); Mücher et al. (2010); Müller and Thiemeyer (2014); and Waroszewski et al. (2013).

For instance, the signs of soil mass transport and mixing along the slope were represented by the shape and distribution of coarse fragments within the horizons (Table 2). The studied soils indicated three different types of influence by slope processes on the coarse fragment distribution. On the one hand, the abrupt increase and random arrangement of coarse fragments was often seen between the upper/upper and middle and lower horizons, as in profiles $\mathrm{P}_{2}, \mathrm{P}_{3}, \mathrm{P}_{4}, \mathrm{P}_{5}$ and $\mathrm{P} 6$ (Table 2), where a large change, e.g. from $25 \%$ in 2Bt horizon up to $90 \%$ in $2 \mathrm{Ck} 2$ horizon in case of $\mathrm{P} 2$, was noted. In the case of profile $\mathrm{P} 1$, the content of coarse fragments undoubtedly increased, but after all, represented a high content of coarse fragments within the whole profile (from 30\% Ahk1, to $85 \%$ - $3 \mathrm{C}_{3}$; Table 2). $\mathrm{P} 7$ was an example of a different kind of distribution of coarse fragments, and presented a homogenous but rather low content of rock fragments (from $5 \%-\mathrm{Bt}$ and Btg, to $10 \%$ - 2Btg2 and 2BCtg; Table 2), suggesting that the fine-grained soil material was probably washed out during transport on the slope (Kowalska et al. 2019; Mücher et al. 2010).

Further, the orientation of coarse fragments was evidence of the great impact of the slope processes on the studied soils. An elongated position of rock fragments was noted on some profiles (e.g. profile $\mathrm{P}_{2}$, Figure 4a, b; profile $\mathrm{P}_{3}$, Figure $5 \mathrm{a}, \mathrm{b}$ ), indicating that the material had been subject to gravity-driven processes (Kacprzak et al. 2015; Kowalska et al. 2017; Mücher et al. 2010;
Watson and Watson 1967). Moreover, the coarse fragments mostly had an angular shape (in some samples also subangular, e.g. $\mathrm{P}_{1}, \mathrm{P}_{4}, \mathrm{P}_{5}$ and $\mathrm{P} 6$; Table 2) and random orientation, which could be interpreted as a result of short-distance transport (Dill 1998; Jäger et al. 2015; Waroszewski et al., 2013). Yet the morphology of coarse fragments seen in this study differed from the results of other authors, e.g. Bertran and Texier (1998); Harris (1998); Mücher et al. (2010); and Müller and Thiemeyer (2014), who noted mostly (sub) rounded rock fragments in heterogeneous colluvial soils. However, the common, angular shape of rock fragments in the soils under study could be conditioned by weak intensity or duration of transport on the slope and/or the small distance between the initial spot of displaced material and the site where it ultimately accumulated (Kleber 1997; Kowalska et al. 2019; Lorz et al. 2010).

Together with the shape of coarse fragments and the groundmass character, the coarse and fine size limit (c:f ratio) should be highlighted in terms of assessment of the impact of slope processes on the studied soils' formation. The c:f-related distribution pattern in the studied soils included mostly porphyric (open porphyric, double spaced porphyric, single-spaced porphyric, close porphyric) with various ratios of fine and coarse fragments (Table 5). Based on the determined c:f ratio, it can be assumed that the mixing of materials affected the studied soils differently. Profiles P1, P2 and P3 represented abrupt changes within the coarse and fine size limits at the boundary, where the lithic discontinuity was seen. This may suggest that upper horizons above the lithic discontinuity may have the same origin, which caused the similar arrangement of coarse and fine fragments in those horizons, or the process of mixing overlap extensively contributed to homogenizing of this part of the soil profile (Waroszewski et al. 2018). Following this assumption, in the other soils ( $\mathrm{P}_{4}$, $\mathrm{P}_{5}, \mathrm{P} 6$ and $\mathrm{P}_{7}$ ) where a higher variability in c:f ratio was noted, the degree of mixing process was slightly weaker. Another explanation for such different patterns in the c:f ratio may be the different times and intensity of deposition and accumulation processes of soil material (Stoops and Jongerius 1975; Mücher et al. 1981).

The large influence of slope processes led to heterogeneity in fine-grained material distribution 
as well. The alternation between the content of the fine and very fine sand and silt fractions was noticeable (Table 3), giving rise to the three main patterns in fine-grain size distribution in the studied soils and showing the various effects of slope processes. In the soils P1 and P6, the surface horizons had a strictly fine-sandy character (horizons Ahk1 and Ahk2 - soil P1, horizon A - soil P6; Table 3), however, a sudden decrease in the content of fine and very fine sand in favour of silt was stated. Such patterns could not be exclusively the result of sandstone weathering, therefore most likely these surface horizons were deposited as a result of soil material transport down the slope (Waroszewski et al. 2013). Furthermore, profiles $\mathrm{P}_{2}, \mathrm{P}_{3}, \mathrm{P}_{4}$ and $\mathrm{P}_{5}$ were characterized by a silty character in both the surface and lower horizons. Nonetheless, the content of fine and very fine sand gradually decreased, suggesting at least two reasons for this decrease: i) the allochthonous, aeolian input of fine fractions within the whole profile and/ or ii) gradual accumulation of soil material through e.g. grain-flow deposits (Mücher et al. 2010 and literature cited therein). On the other hand, in soil $\mathrm{P}_{7}$, the distribution of the finegrained fraction was quite varied, hence a high degree of mixing could be supposed in this case (Waroszewski et al. 2018).

The studied soils indicated an irregular arrangement of b-fabric patterns (Table 5), which may be derived from both the soil chemical features, such as calcium carbonate content distribution and mineralogical characteristics and texture, as well as undoubtedly soil material transport on the slope and its intensity. The presence of a partially crystallitic b-fabric in soils $\mathrm{P}_{1}, \mathrm{P}_{2}$ and $\mathrm{P}_{3}$ may be connected with the high content of randomly distributed small crystals of calcite (or other minerals like quartz) and the occurrence of recrystallized, secondary forms of calcium carbonate (Figure 3d, f; Figure 4d, f; Figure 5d; Table 5). Often, porostriated, granostriated and speckled b-fabric patterns were noted due to oriented clay domains around voids or aggregates (Bullock et al. 1985), as in case of $\mathrm{P}_{2}, \mathrm{P}_{3}$, $\mathrm{P}_{4}, \mathrm{P}_{5}, \mathrm{P} 6$, and $\mathrm{P}_{7}$ (Figure 5b, f; Figure 6d, f; Figure 7b, d, f; Figure 8b; Figure 9b, f; Table 5). Rarely, the partially undifferentiated b-fabric pattern was visible on studied thin sections, suggesting masking of the interference colour in the micromass (Stoops 2003). Usually, the soils showed a very heterogeneous arrangement of bfabric patterns among the soil profile as well as their coexistence in one horizon, which most likely resulted from transport and deposition of the soil material prior to reworking by mass movement on the slope (Gerasimova and Lebedeva-Verba 2010; Harris 1998; Kovda and Mermut 2010; Mücher et al. 2010).

Iron-manganese impregnations (Table 5; Figure 4a, c, e; Figure 5e; Figure 6c; Figure 7b; Figure 9e) and rounded orthic nodules (Table 5) recognized in studied thin sections were usually characterized by gradual (diffuse) boundaries. According to the literature, orthic nodules and iron-manganese impregnations are generally formed in situ and not moved (Stoops et al. 2010). As noted by Lindbo et al. (2010) and the literature cited therein, rounded orthic nodules and ironmanganese impregnations have been considered as a reflection of current soil hydrology, especially short periods of water and moderate rainfall; this is consistent with the water conditions of the studied soils (Table 1). However, McCarthy et al. (1998) consider the rounded shape of impregnations and nodules as evidence of being transported not formation in situ. Considering the fact that studied soils are supposed to be under strong soil material translocation processes on these slopes, the assumption of McCarthy et al. (1998) seems reasonable.

\subsection{The relations between layering of slope deposits and calcium carbonate distribution in soils}

The translocation and mixing processes of the soil material on the slopes highly influenced the distribution of primary and secondary calcium carbonate within the studied soil profiles. Similar findings have been seen by other authors studying carbonate soils, e.g. Badía et al. 2013; Kacprzak and Salamon 2013; Kowalska et al. 2019. In this study, primary (lithogenic) calcium carbonate occurred mostly due to the presence and weathering of calcium carbonate coarse fragments, e.g. limestone, sandstone and shale, throughout the profile (Tables 1 and 2, Figure 2). Contrarily, secondary (pedogenic) carbonate formation was an outcome of the pedogenic process, i.e. dissolution 
and precipitation (Ferńandez-Ugalde et al. 2010; Zamanian et al. 2016). The process of evapotranspiration could ensure secondary carbonate movement (upward) and diffusion (unidirectional) (Ferńandez-Ugalde et al. 2010; Zamanian et al. 2016).

Primary calcium carbonate enrichment was detected in all soil horizons of $\mathrm{P}_{1}, \mathrm{P}_{2}$ and $\mathrm{P}_{3}$ (Table 4; Figure 2). Nonetheless, within the profiles $\mathrm{P}_{4}$, $\mathrm{P}_{5}, \mathrm{P}_{6}$ and $\mathrm{P}_{7}$, a sudden reduction of calcium carbonate content was noted, mostly in the $\mathrm{A}, \mathrm{AB}$ and/or B horizons (Table 4). This seems to be the result of leaching of calcium carbonate in less stable soil conditions, causing a neutral or slightly acidic reaction of the soil (Gunal and Ransom 2006; Rubio and Escudero 2005; Scheatzl and Anderson 2005). However, in the case of heterogeneous soils located on slopes, the loss of carbonates from soil by leaching (decarbonation) is sometimes doubtful (Alijani and Sarmadian 2014; Badía et al. 2013). Thus, different causes leading to carbonate removal should be emphasized. First, erosion and deposition of the non-carbonate material on the surface of in-situ soil might be one reason for the patterns of calcium carbonate distribution seen (Kacprzak and Derkowski 2007; Reheis et al. 1992). On the other hand, the primary calcium carbonate could be removed from the soil substrate upon the start of mass wasting processes, and then postsedimentary processes (pedogenesis) can be launched (Ciolkosz et al. 1979; Kleber 1997).

While the reasons for primary calcium carbonate distribution within soil seem to be fairly obvious, the presence and arrangement of secondary carbonates is more complex. According to thin-section observations, the pedogenic carbonates were visible only in soils of Group 1 $\mathrm{P}_{1}, \mathrm{P}_{2}$ and $\mathrm{P}_{3}$ (see Section 3.3). It has been widely reported in the literature that one of the significant factors controlling the pedogenic carbonate formation and localization are climate conditions, i.e. temperature and the sum of precipitation and evaporation (Egli and Fitze 2001; Hough et al. 2014; Landi et al. 2003; Zamanian et al. 2016). As was noted by other authors (e.g. Birkeland 1999; Zamanian et al. 2016) pedogenic carbonates can be formed during the process of soil drying, when the evapotranspiration exceeds the precipitation. Although, arid and semiarid climates seem to be ideal for pedogenic carbonate formation, due to the long evaporation-dominant stage, which favours the concentration stage over the dissolving stage occurring during precipitation periods (Borchardt and Lienkaemper 1999), often the presence of secondary carbonates are also noted in colder regions such as temperate climates. The climatic conditions prevailing in the studied area completely allow the formation of secondary carbonate forms (Table 1). Especially, the precipitation regime is the most important agent here, which controls the depth where pedogenic carbonates can be leached and accumulated (Candy and Black 2009; Egli and Fitze 2001; Kuznetsova and Khoklova 2012). It is accepted that the accumulation of secondary carbonates requires a at least a mean amount of precipitation about 500 mm per year (Gocke and Kuzyakov 2011; Zamanian et al. 2016).

On the other hand, it is suggested that increasing dryness and evaporation increases the rate of carbonate precipitation (Candy and Black 2009). Gocke and Kuzyakov (2011) noted that the temperature is the key factor; the lowest rates of carbonate accumulation are supposed to occur at $10^{\circ} \mathrm{C}$ and the highest at $30^{\circ} \mathrm{C}$. Following this assumption, the mean average annual temperature at the studied area is below $10^{\circ} \mathrm{C}$ (Table 1), which suggests that the intensity of carbonate precipitation was rather low. Furthermore, such low intensity together with relatively moderate rainfall could contribute to the development of secondary carbonates of small size that usually become more irregular with broken faces (Figure 3: f) or holes (Figure 3f, Figure 4f) (Kuznetsova and Khoklova 2012).

However, taking into account comparable climatic conditions in all studied soil profiles the question arises why the pedogenic carbonates were able to develop only in soils $\mathrm{P}_{1}, \mathrm{P}_{2}$ and $\mathrm{P}_{3}$ ? It is supposed that the first reason is the very high content of primary calcium carbonate and generally very stable conditions in these soils: high $\mathrm{pH}$, high base saturation, moderate moisture, etc., which do not allow secondary carbonate dissolution (Zamanian et al. 2016).

Nonetheless, a different distribution of secondary calcium carbonates was recognized in Group 1. Within soil P1, pedogenic carbonates enriched the soil profile down to depths of $65 \mathrm{~cm}$ (Table 5). This soil was characterized by loam 
texture, with the clear addition of sand in its upper part. Such a character of the soil mantle (sanddominated) provides conditions for the easy leaching of carbonates (Durand et al. 2010; Wieder and Yaalon 1974). This prompts the question of why would calcium carbonates then remain in the soil? We can only speculate that the slope cover from which soil P1 developed was deposited quite recently and the secondary calcium carbonates have just formed (Durand et al. 2010; Zamanian et al. 2016). This hypothesis is supported by the occurrence of dispersed very small-sized secondary calcium carbonate forms, e.g. nodules (about $1 \mathrm{~mm}$, Figure 3d, f), and by soft forms like impregnations, which may be evidence of being in a very early stage of development (Gile 1993; Kovda et al. 2003; Zamanian et al. 2016). Furthermore, the loose material might also provide the conditions for easy movement of pedogenic calcium carbonate within the soil profile; this is why in the relatively young sediments the secondary forms were present in almost the entire soil column (e.g. profile P1).

A different case is shown in the profiles $\mathrm{P} 2$ and P3. No clear trend can be established, as the content of primary calcium carbonate was rather various between the soil horizons (Table 4, Figure 2). Within those soils, the pedogenic calcium carbonates were present in the lower parts of the soil profile (Table 5). This may be because the fact that soil material from the upper part, being under a slope process, could have been partially decalcified; the content of calcium carbonate was noticeably lower at depths of 60 and $20 \mathrm{~cm}$ and below in $\mathrm{P}_{2}$ and $\mathrm{P}_{3}$, respectively, compared to the lower-lying horizons. On the other hand, the secondary calcium carbonate preservation in lower-lying horizons (horizons: $2 \mathrm{BkC}$ and $2 \mathrm{Ck} 1 \mathrm{in}$ soil $\mathrm{P} 2$ and 2BCk, 2BCkt1 and 2BCkt2 in soil $\mathrm{P}_{3}$ ) may be related to the texture. The horizons in which pedogenic carbonates were seen had a loam and clay loam texture, which tends to prevent pedogenic carbonate movement (Wieder and Yaalon 1982).

Due to the arrangement of lithogenic calcium carbonate in $\mathrm{P}_{4}, \mathrm{P}_{5}, \mathrm{P} 6$ and $\mathrm{P}_{7}$ (Group 2 and 3) and the absence of its pedogenic forms, it is not certain if the soils were enriched in calcium carbonate or whether its carbonation was caused by slope processes. Even if the soils had a high content of calcium carbonate in the entire profile at the beginning of their formation, slope processes (e.g. soil washing, mixing) could lead to depletion or loss of calcium carbonate from the soil material (Alijani and Sarmadian 2014). As the result, the calcium carbonate was preserved in horizons that were not under strong redeposition processes (Kowalska et al. 2019). In such unstable environments, where even primary calcium carbonate forms are barely preserved, development of secondary carbonates was most likely not possible. Similar findings were noted in soils developed on loess-like sediments, where complete remodelling of carbonate loess might lead to a disappearance of primary carbonate in the soil profile (Li et al. 2017; Pye 1987; Waroszewski et al. 2018; Zasoński 1983).

\section{Conclusions}

The heterogeneous character of the studied soils was seen in the occurrence and distribution of several micromorphological features. Mostly, increasing content and random arrangement of angular and subangular coarse fragments were noted between the upper, middle and lower parts of the profiles, suggesting re-depositional processes. The slope processes led to stratification, as evidenced in the soil profile through e.g. various c:f ratios. On the one hand, the strongest differences in c:f ratio were noted at the boundary of the lithic discontinuity. On the other, it is likely that a similar origin or the advanced mixing of soil material led to homogenization and resulted in less different c:f ratios within the profile. The presence and irregular distribution of various types of bfabric (e.g. crystallitic, porostriated, granostriated and speckled) were very likely due to a derivative of both the soil features, such as secondary calcium carbonate content, mineralogical characteristics and texture, as well as soil material transport on the slope.

The climate conditions (temperature, precipitation, evaporation) prevailing in the area favour the development of secondary forms of calcium carbonate. However, only three of the seven profiles had pedogenic forms of calcium carbonate, distributed randomly. Occurrence, distribution and preservation of secondary carbonates mainly depend on a high content of 
primary calcium carbonate and soil features such as texture. On the other hand, the material transported down the slope might indicate a lack of or a very low content of primary calcium, hence its pedogenic forms could not be created. The slope

\section{Acknowledgments}

This research was financed by the National Science Centre (Poland) (PRELUDIUM 14 project no. 2017/27/N/ST10/o0342) and the Ministry of Science and Higher Education of the Republic of Poland, No. BM-4112/17 and BM-2120/18. The authors are indebted to the reviewers for their constructive remarks and comments on an earlier version of the manuscript as well as to Professor Juan Carlos Loaiza Usuga and Jarosław Waroszewski, Ph.D. for all scientific advice regarding micromorphology.

\section{References}

Alijani Z, Sarmadian F (2014) The role of topography in changing of soil carbonate content. Indian J.Sci.Res 6: 263271. https://doi.org/10.5897/JSSEM2016.0574

Alonso P, Dorronsoro C, Egido JA (2004) Carbonatation in palaeosoils formed on terraces of the Tormes river basin (Salamanca, Spain). Geoderma 118: 261-276. https://doi.org/10.1180/0009855054010157

Badía D, Martí C, Aznar JM, León J (2013) Influence of slope and parent rock on soil genesis and classification in semiarid mountainous environments. Geoderma 193-194: 13-21. https://doi.org/10.1180/0009855054010157

Bertran P, He'tu B, Texier JP, van Steijn H (1997) Fabric characteristics of subaerial slope deposits. Sedimentology 44: 1-16. https://doi.org/10.1111/j.1365-3091.1997.tboo421.x

Bertran P, Texier JP (1999) Facies and microfacies of slope deposits. Catena 35: 99-121. https://doi.org/10.1016/So341-8162(98)ooo96-4

Birkeland P (1999) Soils and Geomorphology. Oxford University Press. p 448. https://doi.org/10.1002/esp.242

Bockheim JG, Douglass DC (2006) Origin and significance of calcium carbonate in soils of southwestern Patagonia. Geoderma 136: 3-4, 751-762. https://doi.org/10.1016/j.geoderma.2006.05.01

Borchardt G, Lienkaemper JJ (1999) Pedogenic calcite as evidence for an early Holocene dry period in the San Francisco Bay area, California. Geological Society of America Bulletin 111: 906-918

Bullock P, Fedoroff N, Jongerius A, et al. (1985) Handbook for Soil Thin Section Description. Waine Research Publications Wolverhampton, UK. p 152.

Candy I, Black S, Sellwood BW (2005) U-series isochron dating of immature and mature calcretes as a basis for constructing Quaternary landform chronologies for the Sorbas basin, southeast Spain. Quaternary Research 64: 100-111. https://doi.org/10.3390/quat1020015

Ciolkosz EJ, Peterson GW, Cunningham RL (1979) Soils developed from colluvium in the Ridge and Valley area of processes may lead to depletion or loss of calcium carbonate from soil material. In such unstable conditions, where even primary calcium carbonate was barely preserved, the formation of secondary carbonates was most likely not possible.

Open Access This article is distributed under the terms of the Creative Commons Attribution 4.0 International License (http://creativecommons. org/licenses/by/4.0/), which permits unrestricted use, distribution, and reproduction in any medium, provided you give appropriate credit to the original author(s) and the source, provide a link to the Creative Commons license, and indicate if changes were made.
Pennsylvania. Soil Science 128: 153-162.

https://doi.org/10.1097/00010694-197909000-00004

Dill HG (1998) A review of heavy minerals in clastic sediments with case studies from the alluvial-fan through the nearshoremarine environments. Earth Science Reviews 45: 103-132. https://doi.org/10.1016/Soo12-8252(98)00030-o

Durand N, Gunnell Y, Curmi P, Ahmad SM (2007) Pedogenic carbonates on Precambrian silicate rocks in South India: Origin and paleoclimatic significance. Quaternary International 162/163: 35-49.

Durand N, Monger HC, Canti MG (2010) Calcium carbonate features. In: Stoops G, Marcelino V, Mees F (eds.), Interpretation of Micromorphological Features of Soils and Regoliths. Elsevier, Amsterdam. pp 149-194. https://doi.org/10.1016/C2009-0-18081-9

Egli M, Fitze P (2001) Quantitative aspects of carbonate leaching of soils with differing ages and climates. Catena 46:35-62. https://doi.org/10.1016/So341-8162(01)00154-0

FAO (2006) Guidelines for soil description. Fourth Edition. Rome. p 109.

Fernández-Ugalde O, Virto I, Imaz MJ, et al. (2010) Relative contribution of naturally-occurring carbonates and soil organic carbon to soil aggregation dynamics. Soil Solutions for a Changing World 194-197.

Gargiulo L, Mele G, Terribile F (2013) Image analysis and soil micromorphology applied to study physical mechanisms of soil pore development: An experiment using iron oxides and calcium carbonate. Geoderma 197-198:151-160. https://doi.org/10.1016/j.geoderma.2013.01.008

Gerasimova M, Lebedeva-Verba M (2010) Topsoils -mollic, takyric and yermic horizons. In: Stoops G, Marcelino V, Mees $\mathrm{F}$ (eds.), Interpretation of Micromorphological Features of Soils and Regoliths. Elsevier, Amsterdam. pp 351-368. https://doi.org/10.1016/C2009-0-18081-9

Gile LH (1993) Carbonate stages in sandy soils of the Leasburg surface, southern new Mexico. Soil Science 156: 101-110. https://doi.org/10.1097/00010694-199308000- 00006 
Gocke M, Kuzyakov Y (2011) Effect of temperature and rhizosphere processes on pedogenic carbonate recrystallization: relevance for paleoenvironmental applications. Geoderma 166: 57-65.

https://doi.org/10.1016/j.geoderma.2011.07.011

Govers G, Vandaele K, Desmet PJJ, et al. (1994) The role of soil tillage on soil redistribution on hillslopes. European Journal of Soil Science 45: 469-478.

https://doi.org/10.1111/j.1365-2389.1994.tboo532.x

Gunal H, Ransom MD (2006) Genesis and micromorphology of loess-derived soils from central Kansas. Catena 65(3): 222236. https://doi.org/10.1016/j.catena.2005.11.018

Harris C (1981) Microstructures in solifluction sediments from South Wales and North Norway. Biuletyn Peryglacjalny 28: 221-226.

Harris C, Ellis S (1980) Micromorphology of soils in soliflucted materials, Okstindan, Northern Norway. Geoderma 23: 11-29. https://doi.org/10.1016/0016-7061(80)90046-4

Harris C (1998) The micromorphology of paraglacial and periglacial slope deposits: a case study from Morfa Bychan, west Wales, UK. Journal of Quaternary Science 13: 73-84. https://doi.org/10.1002/(sici)1099-

1417(199801/o2)13:1<73::aid-jqs315>3.3.co;2-g

Hough B, Fan M, Passey BH (2014) Calibration of the clumped isotope geothermometer in soil carbonate in Wyoming and Nebraska USA: implications for paleoelevation and paleoclimate reconstruction. Earth and Planetary Science Letters 391:110-120.

https://doi.org/10.1016/j.epsl.2014.01.008

IUSS Working Group WRB (2015) World Reference Base for Soil Resources 2014, update 2015. International soil classification system for naming soils and creating legends for soil maps. World Soil Resources Reports No. 106. FAO, Rome. p 182.

Jäger H, Achermann M, Waroszewski J, et al. (2015) Pre-alpine mire sediments as a mirror of erosion, soil formation and landscape evolution during the last $45 \mathrm{ka}$. Catena 128: 63-79. https://doi.org/10.1016/j.catena.2015.01.018

Kacprzak A, Derkowski A (2007) Cambisols developed from cover-beds in the Pieniny Mts. (southern Poland) and their mineral composition. Catena 71: 292-297.

https://doi.org/10.1016/j.catena.2007.01.004

Kacprzak A, Salamon P (2013) Properties and classification of soils developed from aeolian and flysch materials in the Wieliczka Foothills (Southern Poland). Gruntoznavstvo 14(34): 52-62.

Kacprzak A, Szymański W, Wójcik-Tabol P (2015) The role of flysch sandstones in forming the properties of cover deposits and soils - examples from the Carpathians. Zeitschrift für Geomorphol 59: 227-245.

https://doi.org/10.1127/zfg_suppl/2015/S-00182

Kacprzak A, Żyła M (2006) Micromorphology of "brown pararendzina soils" (Skeleti Endoleptic Cambisols) developed from slope covers in the Pieniny Mts. Pieniny - Przyroda i Człowiek 9: 51-61. (In Polish with English summary)

Kehl M, Álvarez-Alonso D, De Andrés-Herrero M, et al. (2018) Towards a revised stratigraphy for the middle to upper palaeolithic boundary at la güelga (Narciandi, Asturias, Spain). Soil Micromorphology and New Radiocarbon Data. Boletin Geologico y Minero 129(1-2): 183-206. https://doi.org/10.21701/bolgeomin.129.1.008

Kleber A (1997) Cover-beds as soil parent materials in midlatitude regions. Catena 30: 197-213.

https://doi.org/10.1016/So341-8162(97)0oo18-o

Kociałkowski W, Pokojska U, Sapek B (1984) Guide for determining the sorption capacity of soil. Works of Scientific Committees - PTG. Warszawa. p 94. (In Polish)

Kolesár M, Čurlik J (2015) Origin, distribution and transformation of authigenic carbonates in loessic soils. Eurasian Journal of Soil Science 4: 38-43.

https://doi.org/10.21701/bolgeomin.129.1.008

Kowalska J, Kajdas B, Zaleski T (2017) Variability of morphological, physical and chemical properties of soils derived from carbonate-rich parent material in the Pieniny Mountains (south Poland). Soil Science Annual 68 (1): 27-38. https://doi.org/10.1515/ssa-2017-0004

Kowalska JB, Zaleski T, Józefowska A, Mazurek R (2019) Soil formation on calcium carbonate-rich parent material in the outer Carpathian Mountains - A case study. Catena 174: 436451. https://doi.org/10.1016/j.catena.2018.11.025

Kovda IV, Wilding LP, Drees LR (2003) Micromorphology, submicroscopy and microprobe study of carbonate pedofeatures in a Vertisol gilgai soil complex, South Russia. Catena, Achievements in Micromorphology 54: 457-476. https://doi.org/10.1016/So341-8162(o3)00121-8

Kovda I, Mermut A (2010) Vertic features. In: Stoops G, Marcelino V, Mees F (eds.), Interpretation of Micromorphological Features of Soils and Regoliths. Elsevier, Amsterdam. pp 109-127. https://doi.org/10.1016/C2009-0-18081-9

Kuznetsova AM, Khokhlova OS (2012) Submicromorphology of pedogenic carbonate accumulations as a proxy of modern and paleoenvironmental conditions. Boletin de la Sociedad Geologica Mexicana 64: 199-205.

Kuźniar A, Twardt S, Kowalczyk A, Kostych M (2011) An assessment of the water requirements of a mountain pasture sward in the Polish Western Carpathians. Journal of Water and Land Development, 15: 193-207.

Landi A, Mermut AR, Anderson DW (2003) Origin and rate of pedogenic carbonate accumulation in Saskatchewan soils, Canada. Geoderma 117: 143-156.

https://doi. org/10.1016/Soo16-7061(03)oo161-7

Li Y, Zhao J, Li B (2017) Loess and Loess Geohazards in China (1st Edition). Taylor \& Francis Ltd. p 160. https://doi.org/10.1201/9781315177281

Lindbo DL, Stolt MH, Vepraskas MJ (2010). Redoximorphic features. In: Stoops G, Marcelino V, Mees F. (eds.), Interpretation of Micromorphological Features of Soils and Regoliths. Elsevier, Amsterdam. pp 129-147. https://doi.org/10.1016/C2009-0-18081-9

Lityński T, Jurkowska H, Gorlach E (1976) ChemicalAgricultural Analysis. PWN, Warszawa. p 332. (In Polish)

Lorz C, Frühauf M, Mailänder R, Phillips JD (2010) Lithologic Discontinuities in Cover Beds Influencing Soil Evolution and Soil Properties. Geophysical Research Abstracts, EGU General Assembly 12: 1-3.

McCarthy PJ, Martini IP, Leckie DA (1998) Use of micromorphology for palaeoenvironmental interpretation of complex alluvial paleosols: an example from the Mill Creek Formation (Albian), southwestern Alberta, Canada. Palaeogeography, Palaeoclimatology, Palaeoecology 143: 87110. https://doi.org/10.1016/Soo31-0182(98)ooo80-7

Munsell (1975) Standard Soil Color Charts. Munsell Color Co, Baltimore, MD. p 29.

Mücher HJ, De Ploey J, Savat J (1981) Response of loess materials to simulated translocation by water: micromorphological observations. Earth Surface Processes and Landforms 6: 331-336.

https://doi.org/10.1002/esp.3290060312

Mücher HJ, Morozova TD (1983) Theapplication of soil micromorphology in Quaternary geology and geomorphology. In: Bullock P, Murphy CP (eds.), Soil Micromorphology. Volume 1. Techniques and Applications. AB Academic Publishers, Berkhamsted, UK. pp 151-194

Mücher H, van Steijn H, Kwaad F (2010) Colluvial and mass wasting deposits. In: Stoops G, Marcelino V, Mees F. (eds.), Interpretation of Micromorphological Features of Soils and Regoliths. Elsevier, Amsterdam. pp 37-48. https://doi.org/10.1016/C2009-0-18081-9

Müller S, Thiemeyer H (2014) Formation and transformation of Pleistocene periglacial slope deposits in the Spessart Mountains (Hesse, Germany). Zeitschrift Für Geomorphologie, Supplementary Issues 58(3): 91-113. https://doi.org/10.1127/0372-8854/2014/S-00157 
Otrebska-Starklowa B, Hess M, Olecki Z, et al. (1995) Klimat. In: Warszyńska J (eds.), Karpaty Polskie. Uniwersytet Jagielloński. pp 31-48. (In Polish).

Phillips JD, Lorz C (2008) Origins and implications of soil layering. Earth-Science Reviews, 89(3-4), 144-155. https://doi.org/10.1016/j.earscirev.2008.04.003

Polish Standard (1998) Soil and mineral soil materials sampling and determination of particle size distribution. PNR-04032. Polish Committee for Standardization Warszawa. (In Polish)

Pye K (1987) Aeolian Dust and Dust Deposits (1st Edition). Academic Press. p 334.

Reheis MC, Sowers JM, Taylor EM, et al. (1992) Morphology and genesis of carbonate soils on the Kyle Canyon fan, Nevada, U.S.A. Geoderma 52(3-4): 303-342. https://doi.org/10.1016/0016-7061(92)90044-8

Reeves CC (1970) Origin, classification and geologic history of caliche on the southern high plains, Texas and eastern New Mexico. Journal of Geology 78: 352-362.

Rubio A, Escudero A (2005) Effect of climate and physiography on occurrence and intensity of decarbonation in Mediterranean forest soils of Spain. Geoderma 125(3-4): 309319. https://doi.org/10.1016/j.geoderma.2004.09.005

Schaetzl R, Anderson S (2005) Soils, Genesis and Geomorphology. Cambridge University Press. p 817.

Sehgal JL, Stoops G (1972) Pedogenic calcic accumulation in arid and semiarid regions of the Indo-Gangetic alluvial plain of the erstwhile Punjab (India). Their morphology and origin. Geoderma 8: 59-72.

Skiba S (1995) Soil cover. In: Warszyńska J (eds.), Polish Carpathians. Uniwersytet Jagielloński. pp 69-76. (In Polish)

Stoops G, Jongerius A (1975) Proposal for a micromorphological classification of soil minerals. I. A classification of the related distributions of the fine and coarse particles. Geoderma 13: 189-199. https://doi.org/10.1016/0016-7061(75)90017-8

Stoops G (2003) Guidelines for analysis and description of soil and regolith thin sections. Soil Science Society of America, Inc. Madison, Wisconsin, USA. p 184 https://doi.org/10.1017/Soo2185960322339X

Stoops G, Marcelino V, Mees F (2010) Micromorphological Features and Their Relation to Processes and Classification: General Guidelines and Keys. In: Stoops G, Marcelino V, Mees F, (eds.), Interpretation of Micromorphological Features of Soils and Regoliths. Elsevier, Amsterdam. pp 1536. https://doi.org/10.1016/C2009-0-18081-9

van Muijsen W, Govers G, van Oost K (2002) Identification of important factors in the process of tillage erosion: the case of mouldboard tillage. Soil \& Tillage Research 6: 77-93. https://doi.org/10.1016/S0167-1987(01)00282-3

van Oost K, Govers G, Desmet P (2000) Evaluating the effects of changes in landscape structure on soil erosion by water and tillage. Landscape Ecology 15: 577.

https://doi.org/10.1023/A:1008198215674
Waroszewski J, Kalinski K, Malkiewicz M, et al. (2013) Pleistocene-Holocene cover-beds on granite regolith as parent material for Podzols - An example from the Sudeten Mountains. Catena 104: 161-173.

https://doi.org/10.1016/j.catena.2012.11.006

Waroszewski J, Malkiewicz M, Mazurek R, et al. (2015) Lithological discontinuities in Podzols developed from sandstone cover beds in the Stolowe Mountains (Poland). Catena 126: 11-19. https://doi.org/10.1016/j.catena.2014.10.034

Waroszewski J, Sprafke T, Kabala C, et al. (2018) Aeolian silt contribution to soils on the mountain slopes (Mt. Ślęża, SW Poland). Quaternary Research 89(3): 702-717. https://doi.org/10.1017/qua.2017.76

Watson E, Watson S (1967) The periglacial origin of the drifts at Morfa-Bychan, near Aberystwyth. Geological Journal 5: 419440. https://doi.org/10.1002/gj.3350050212

Wieder M, Yaalon DH (1974) Effect of matrix composition of carbonate nodule crystallisation. Geoderma 11: 95-121. https://doi.org/10.1016/0016-7061(74)90010-X

Wieder M, Yaalon DH (1982) Micromorphological fabrics and developmental stages of carbonate nobular forms related to soil characteristics. Geoderma 28: 203-220. https://doi.org/10.1016/0016-7061(82)90003-9

Zagórski Z (1999) Micromorphology and some properties calcareous soils from Male Pieniny. Roczniki Gleboznawcze Soil Science Annual 50(1-2): 115-126. (In Polish with English summary)

Zamanian K, Pustovoytov K, Kuzyakov Y (2016) Pedogenic carbonates: Forms and formation processes. Earth-Science Rev 157: 1-17. https://doi.org/10.1016/j.earscirev.2016.03.003

Zasoński S (1983) Chief soil-forming processes on very fine sand rocks of the Wieliczka Foothills. Part I. General description of soils and some of their chemical properties. Soil Science Annual 24(4):123-159.

Zasoński S (1992) Krosno layers as a parent rock of flysh pararendzinas (exemplified by soils of Rymanów uplands). Soil Science Annual 43( 3/4): 77-90. (In Polish with English summary)

Zasoński S (1993) Calcareous soils derived from selected lithostratigraphical units of East Carpathian flysh. Part I. General description of soils. Soil Science Annual 44 (3/4): 121-133. (In Polish with English summary)

Zasoński S (1995a) Calcareous soils derived from selected lithostratigraphical units of East Carpathian flysh. Part II. Micromorphological properties. Soil Science Annual 46(1/2): 119-134. (In Polish with English summary)

Zasoński S (1995b) Calcareous soils derived from selected lithostratigraphical units of East Carpathian flysh. Part III Mineral composition of the clay fraction. Soil Science Annual 46(3/4): 45-57. (In Polish with English summary) 